\title{
Terrorism offences in Belgian criminal law: is less more?
}

\author{
Ward Yperman*
}

\begin{abstract}
EU Directive 2017/541 of 15 March 2017 on combating terrorism requires member states to criminalize certain conduct. Belgium implemented the Directive by creating several terrorist offences, which resemble the wording of the Directive. However, some of these offences are beyond the scope of the Directive. Since the Directive already is quite broad and vague, this means the Belgian offences are even broader and sometimes also vaguer. This paper gives a detailed description of the existing Belgian terrorism offences, pointing out issues of broadness and vagueness, as well as overlap between the different offences. This ambiguity seems to be at odds with the legality principle which requires clear and well-defined offences. The paper concludes that Belgium should have implemented the wording of the Directive more precisely. The EU in turn could review the necessity and wording of the different terrorism offences in the Directive. Having fewer offences which are crafted more precisely would already go a long way in solving the ambiguity of these offences.
\end{abstract}

\section{Introduction}

Terrorism has in recent years been a very prominent issue in many states, leading them to expand their counterterrorism arsenal. This happened under the impulse of actors such as the European Union, the Council of Europe and the United Nations. ${ }^{1}$ One part of the counterterrorism approach has been the creation of terrorism offences. For the EU, this part evolved in three stages. In 2002 the Council of the EU adopted the Framework Decision on combatting terrorism. ${ }^{2}$ Six years later this Framework Decision was amended by another one. ${ }^{3}$ Finally, in 2017, the Directive on combatting terrorism (hereafter 'the Directive') was adopted, replacing the Framework Decision. ${ }^{4}$

\footnotetext{
* $\mathrm{PhD}$ researcher and teaching assistant, Institute for Criminal Law, KU Leuven.

${ }^{1}$ E.g.: Council of Europe Convention on the Prevention of Terrorism, Warsaw, 16 May 2005; UNSC Resolution 2178, 24 September 2014, 6(a), <http://unscr.com/en/resolutions/2178> (accessed 12 June 2020). See also: Jan Velaers, 'La Lutte Contre Le Terrorisme et Les Droits de l'homme: Dévelopements Récents En Belgique' in P D'Argent, D Renders and M Verdussen (eds), Les Visages de L'Etat, Liber Amicorum Yves Lejeune (Bruylant 2017) 775.

${ }^{2}$ Council Framework Decision 2002/475/JHA of 13 June 2002 on combating terrorism [2002] OJ L164/5.

3 Council Framework Decision 2008/919/JHA of 28 November 2008 amending Framework Decision 2002/475/JHA on combating terrorism [2008] OJ L330/21.

${ }^{4}$ Directive (EU) 2017/541 of the European Parliament and of the Council of 15 March 2017 on combating terrorism and replacing Council Framework Decision 2002/475/JHA and amending Council Decision 2005/671/JHA [2017] OJ L88/6.
} 
Different member states have implemented these international instruments in different ways. This paper focuses on Belgian law, which has a tradition of responding to issues by using the criminal justice system rather than other branches of law such as administrative law. The aforementioned EU instruments are the international instruments which influenced Belgian law the most. In 2003, in response to the original 2002 EU Framework Decision, the Belgian legislature introduced the first Belgian terrorism offences. ${ }^{5}$ Before 2003, there were no specific terrorist offences in Belgian criminal law and terrorism suspects were prosecuted under other 'ordinary' offences. ${ }^{6}$ Most of the other Belgian terrorist offences were introduced in 2013, in response to the second EU Framework Decision (and the Council of Europe Convention on the Prevention of Terrorism). ${ }^{7}$ The most recent amendment to the Belgian terrorism offences was made in 2019 in response to the EU Directive. ${ }^{8}$ This paper will often refer back to these EU instruments, and more specifically to the Directive, since this is the instrument currently in force.

The EU instruments provide for minimum harmonization, which means they require member states to criminalize certain conduct but allow states to go further if desired. ${ }^{9}$ The Belgian legislature chose to expand some of the terrorism offences beyond the scope of the EU instruments, but overall, it adhered quite closely to the wording of the EU instruments. Because of this, comments on the Belgian offences may prove valuable to the criminal justice systems of other European states, whose legislation is also based on those same instruments. Furthermore, the analysis of the Belgian legislation can also serve to highlight issues with the EU Directive itself.

\footnotetext{
${ }^{5}$ Anne Weyembergh and Laurent Kennes, 'Le Titre Iter Du Livre II Du Code Pénal: Des Infractions Terroristes', Droit pénal spécial: tome 1 (Anthémis 2011) 102.

${ }^{6}$ I De La Serna, 'Des Infractions Terroristes', Les Infractions (Larcier 2013) 170 and 173; Adrien Masset, 'Terrorisme' [2013] Postal Memorialis - Lexicon strafrecht, strafvordering en bijzondere wetten 411, T60/8T60/11; Martin Moucheron, 'Délit politique et terrorisme en Belgique : du noble au vil' [2006] Cultures \& conflits 77, paras 1 and 15; Anne Weyembergh and Laurent Kennes, 'Domestic Provisions and Case Law: The Belgian Case' in Francesca Galli and Anne Weyembergh (eds), EU counter-terrorism offences: What impact on national elgislation and case-law? (Editions de l'Université de Bruxelles 2012) 150; Weyembergh and Kennes (n 5) 103104; Alain Winants, 'De invloed van terrorisme op de strafwetgeving: actualia materieel strafrecht' (2019) 14 Nullum Crimen 343, 345.

${ }^{7}$ MvT bij wetsontwerp van 13 november 2012 tot wijziging van Titel 1 ter van het Strafwetboek, Parl. St. Kamer 2012-2013, nr. 53-2502/001, (4) 4. The final two terrorism offences were introduced in 2015 (the traveling offence) and 2016 (the preparation offence). The former was the result of UNSC Resolution 2178 (see footnote 1) and is now also part of the EU Directive. The latter was introduced by the Belgian legislature without any international obligations to do so.

${ }^{8}$ Toelichting bij wetsvoorstel van 6 februari 2019 houdende diverse bepalingen in strafzaken en inzake erediensten, Parl.St. Kamer 2018-2019, nr. 54-3515/001, 99.

${ }^{9}$ Art 1 Directive (EU) 2017/541 (n 4).
} 
This paper starts by giving an overview of all terrorist offences in Belgian criminal law. This includes terrorist attacks ${ }^{10}$, or terrorism stricto sensu, but also terrorism lato sensu ${ }^{11}$. These terrorist offences lato sensu are aimed at people who prepare or facilitate terrorist attacks through involvement in the activities of a terrorist group, provocation to commit terrorism, recruitment for terrorism, providing or receiving training for terrorism (including self-study), terrorist travel, preparing a terrorist attack or financing a terrorist. After an analysis of these offences, a final section of the paper highlights their broadness and vagueness, which leads to significant overlap between the offences. This broadness and vagueness seem to be at odds with the legality principle ${ }^{12}$ which requires clear and well-defined offences. Since the Belgian offences are sometimes broader than the ones in the Directive, Belgium could have reduced the broadness and vagueness of its offences by implement the wording of the Directive more precisely. The EU in turn could review the necessity and wording of the different terrorism offences in the Directive. Having less offences which are crafted more precisely would already go a long way in solving the ambiguity of these offences.

\section{Terrorist offences in Belgian criminal law}

\subsection{Terrorist attacks}

\subsubsection{Actus reus}

First, we turn to what the Directive calls 'terrorist offences', meaning the actual acts of terrorism, also known as terrorism stricto sensu. This offence was part of the original Framework Decision and was introduced into Belgian criminal law in 2003. The Belgian legislature adhered closely to the wording of the European instruments when transposing this offence into Belgian law. It is the core of the terrorism offences, since the mens rea of all of the terrorism offences lato sensu refers (sometimes in combination with other terrorist offences lato sensu) to terrorism stricto sensu (see below). Due to this, any broadness or uncertainty

\footnotetext{
${ }^{10}$ E.g. terrorist murder, terrorist arson, etc. For a more elaborate explanation, see below.

${ }^{11}$ Being all other offences related in some way to terrorism although not covered by the offence of terrorism stricto sensu.

${ }^{12}$ This principle includes the principle of non-retrospectivity, the principle of law making by parliament according to pre-prescribed rules and the principle of clarity and foreseeability of the law. Especially clarity and foreseeability are essential in this context. These underlying principles can be distilled from the literature and roughly encompass the 8 'Fuller criteria': L Besselink, F Pennings and S Prechal, 'Introduction: legality in multiple legal orders' in L Besselink, F Pennings and S Prechal (eds), The Eclipse of the Legality Principle in the European Union (Kluwer 2011) 6-7; U De Vries and L Francot-Timmermans, 'As Good as It Gets: On Risk, Legality and the Precautionary Principle' in L Besselink, F Pennings and S Prechal (eds), The Eclipse of the Legality Principle in the European Union (Kluwer 2011) 26 and 30; G. Hallevy, A Modern Treatise on the Principle of Legality in Criminal Law (Springer 2010), 6-7.
} 
regarding the scope of terrorism stricto sensu has a direct effect on the broadness and vagueness of all the other terrorism offences.

The actus reus of terrorism stricto sensu in Belgium consists of two lists. ${ }^{13}$ Article 137, $\$ 2$ of the Belgian Criminal Code $^{14}$ (hereafter CC) contains the first list. This list consists of criminal offences that are also punishable under Belgian law outside of the context of terrorism, for example murder or hostage taking. ${ }^{15}$ Article 137, $\$ 3 \mathrm{CC}$ contains the second list, which consists of acts that do not constitute criminal offences outside of a terrorism context, for example hijacking a vehicle other than an aircraft or a ship (hijacking those is a pre-existing offence featured in $\S 2$ ), or threatening to commit terrorism stricto sensu. ${ }^{16}$

After its introduction into the CC in 2003, Article 137 was amended three times, each time introducing new possible terrorist offences to the aforementioned lists. Firstly, in 2009 piracy was added to the list of $\S 2$ of potential terrorist offences. ${ }^{17}$ Secondly, in 2013 the legislature changed the reference to the arms legislation (which had been replaced in 2006) ${ }^{18}$ and added a $\S 2,11^{\circ}$, which adds to the list attempts of the standard offences on that list. ${ }^{19}$ Thirdly, the statute of the $5^{\text {th }}$ of May 2019 introduced a new $\S 2,4 \% 1$, which adds the unlawful disturbance of (data in) an IT-system ${ }^{20}$ to the list of possible terrorist offences. The same statute also expanded $\S 3,3^{\circ}$ to radiological weapons. ${ }^{21}$ The addition of attempted standard offences

\footnotetext{
${ }^{13}$ Weyembergh and Kennes (n 6) 152.

${ }^{14}$ Strafwetboek van 8 juni $B S 9$ juni $1867,3133$.

15 Véronique Hameeuw, 'Strafbaarstelling van terroristische misdrijven: van Europees Kaderbesluit tot het Belgische Strafwetboek’ [2005] Tijdschrift voor Strafrecht 2, 5; Winants (n 6) 347.

${ }^{16}$ Elise Delhaise, Infractions terroristes (Larcier 2019) 30; I De La Serna (n 6) 167 and 180; Ignacio De La Serna, 'Des infractions terroristes' in Christian De Valkeneer and Ignacio De La Serna, À la découverte de la justice pénale: Paroles de juriste (Larcier 2015) 207; Alain De Nauw and Franklin Kuty, Manuel de Droit Pénal Spécial (Wolters Kluwer 2014) 17; Johan Delmulle and Stefaan Guenter, 'Gerechtelijke Aanpak Inzake Terrorisme', Strafrecht en Strafprocesrecht (Wolters Kluwer 2006) 4; An Fransen and Jan Kerkhofs, 'Het Materieel Terrorismestrafrecht' in Jan Kerkhofs, Antoon Schotsaert and Philippe Van Linthout (eds), Contra-terrorisme: De gerechtelijke aanpak van terrorisme in België (Larcier 2018) 19-20; Masset (n 6) T60/18.; A De Nauw, 'Titel Iter: Terroristische misdrijven' in A De Nauw (ed), Inleiding tot het bijzonder strafrecht (Wolters Kluwer 2010) (7) 7; Hameeuw (n 15) 5-6; Winants (n 6) 347.

${ }^{17}$ Art 7 wet van 30 december 2009 betreffende de strijd tegen piraterij op zee, BS 14 januari 2010, 1485.

${ }^{18}$ The 'wet van 8 juni 2006 houdende regeling van economische en individuele activiteiten met wapens' replaced the 'wet van 3 januari 1933 op de vervaardiging van, de handel in en het dragen van wapens en op de handel in munitie, gewijzigd bij de wetten van 30 januari en 5 augustus 1991, 9 maart 1995, 24 juni 1996, 18 juli 1997 , 10 januari 1999 en 30 maart 2000'.

${ }^{19}$ Art 2 wet van 18 februari 2013 tot wijziging van boek II, titel Iter van het Strafwetboek, BS 4 maart 2013, 13233. Article 3 of this statute amended Article $138 \mathrm{CC}$ to set the sentence for these attempted standard offences. See also: Delhaise (n 16) 81; Fransen and Kerkhofs (n 16) 19.

${ }^{20}$ Art 550ter, $\$ 1-3$ CC.

${ }^{21}$ Art 74 wet van 5 mei 2019 houdende diverse bepalingen in strafzaken en inzake erediensten, en tot wijziging van de wet van 28 mei 2002 betreffende de euthanasie en van het Sociaal Strafwetboek (1), BS 24 mei 2019 , 50023. See also: Stéphanie De Coensel, 'De Wet Diverse Bepalingen in Strafzaken II: Terroristische misdrijven in lijn met de Europese verplichtingen?’ (2019) 40 Panopticon 211, 212; Winants (n 6) 357.
} 
in 2013 is significant because, in Belgium, attempted standard offences are only punishable when the law explicitly states this (contrary to attempted felonies, which are always punishable). ${ }^{22}$ Consequently, certain attempted terrorist standard offences were not punishable, despite this being one of the obligations of the Directive. ${ }^{23}$

Almost all of the acts listed require human lives to be endangered. However, for offences entailing large-scale destruction or damage, causing significant economic damage is sufficient. ${ }^{24}$ Clearly, it is difficult to draw the line between terrorism and other offences. Some academics have stated that offences which do not constitute violence against people or at least the threat thereof, should not be labelled terrorism. ${ }^{25}$ Indeed, the label 'terrorist' can have farreaching consequences, both within criminal law and criminal procedure ${ }^{26}$ and outside of $\mathrm{it}^{27}$. Despite these concerns, the requirement that significant economic damage is caused, still suffices as it can impact the stability of a nation and indirectly endanger human lives. However, this is not clear in the wording of Article $137 \mathrm{CC}$ despite the Belgian Constitutional Court not finding it to be in violation of the principle of legality. ${ }^{28}$ A better alternative to 'substantial damage' would have been something similar to 'damage that could endanger the stability of the country and the security of its citizens'.

\footnotetext{
${ }^{22}$ Art 53 CC; De La Serna (n 6) 207; Delhaise (n 16) 81; A De Nauw and F Deruyck, Overzicht van het Belgisch algemeen strafrecht (Die Keure / la Charte 2017) 51; Chris Van den Wyngaert and Steven Vandromme, Strafrecht en strafprocesrecht in hoofdlijnen (Maklu 2014) 356.

${ }^{23}$ Art 14.3 Directive (EU) 2017/541 (n 4). Originally art 4.2 Council Framework Decision 2002/475/JHA (n 2). See also: MvT bij wetsontwerp van 13 november 2012 (n 7) 10; Weyembergh and Kennes (n 6) 156; Winants (n 6) 350 .

${ }^{24}$ Art 137, $§ 2,4^{\circ} \mathrm{CC}$; Fransen and Kerkhofs (n 16) 19.

${ }^{25}$ B Ganor, 'Defining terrorism: is one man's terrorist another man's freedom fighter?' [2002] Police Practice and Research (287) 294; B Hoffman, Inside terrorism, revised and expanded edition (Columbia University Press 2006) 40-41; R Jackson, 'In defence of "terrorism": finding a way through a forest of misconceptions' (2011) 3 Behavioral Sciences of Terrorism and Political Aggression (116) 123; J Lutz and B Lutz, Global Terrorism (Routledge 2013) 8-9; A Richards, 'Conceptualizing Terrorism' [2014] Studies in Conflict \& Terrorism (213) 230.

${ }^{26}$ Aggravated sentences, but also procedural exceptions. For an overview and analysis of some of these procedural consequences, see (in Dutch and French): Noémie Blaise and Elise Delhaise, 'La répression des voyages à visée terroriste à l'aune des droits fondamentaux' [2019] Journal Tribunaux 173; Masset (n 6) T60/20-T60/22; Jan Roelandt, 'De strijd tegen het terrorisme: een overzicht van de recente wetgevende ingrepen in het straf(proces)recht' [2017] Nullum Crimen 10; Ward Yperman, 'De bestrijding van terrorisme en strafprocesrecht: vele kleintjes maken een grote' [2019] Tijdschrift voor Strafrecht 8.

${ }^{27}$ W Mucha, 'Polarization, Stigmatization, Radicalization. Counterterrorism and Homeland Security in France and Germany' (2017) 10 Journal for deradicalization 230 - 254; G Mythen, S Walklate and F Khan, "'Why Should We Have to Prove We're Alright?": Counter-terrorism, Risk and Partial Securities', (2012) 2 Sociology 383-398; S Samuel Justin and A Daniel, The Psychology of Terrorism Fears (Oxford University Press 2012) 14; V Tadros, 'Justice and Terrorism', [2007] New Criminal Law Review (658) 685.

${ }^{28}$ See below: Part 2. Broadness, vagueness and overlap.
} 
Delhaise in turn points out that many sexual offences are not on the list, despite the fact that these offences, especially when committed in a systematic manner and on a large scale, are used as a weapon by terrorist organizations. ${ }^{29}$

Article $137 \mathrm{CC}$ also requires that the offence may, given its nature or context, seriously damage a country or an international organization. Belgian legal theory calls this the 'contextual element' of the offence. ${ }^{30}$ This requirement was copied from European instruments. ${ }^{31}$ The damage does not need to have set in already, the possibility for damage is sufficient. ${ }^{32}$ This 'contextual element' takes into account not just the nature of the offence, but also its wider consequences for the organization and government of a country. ${ }^{33}$ However, viewing contextual information as a separate element is unnecessary. Taking into account contextual information (legal facts) when defining an offence is something that happens regularly. For example for the offence of raping a person of less than fourteen years old ${ }^{34}$, the age of the victim is part of the actus reus of the offence ${ }^{35}$ and for bankruptcy offences ${ }^{36}$, the fact that the company is bankrupt is part of the actus reus as well. Legal facts such as these are part of the actus reus of those offences, as is the case for terrorism stricto sensu.

\subsubsection{Mens Rea}

The required mens rea is a form of special intent. ${ }^{37}$ The offence needs to be committed 'with the aim of seriously intimidating a population, or unduly compelling a government or international organization to perform or abstain from performing any act, or seriously

\footnotetext{
${ }^{29}$ Delhaise (n 16) 30. Note that this is mainly the case in quasi-war situations outside of Europe (for example in the Middle East or Africa). It seems that the definition is mainly shaped by the type of terrorism that we have experienced in Europe so far.

30 De La Serna, 2013 (n 11) 177; De La Serna, 2015 (n 11) 204-205; Delhaise (n 11) 28-29; Fransen and Kerkhofs (n 11) 21; Winants (n 10) 347. Hameeuw states that the wording of what others call the contextual element is so broad that it cannot constitute a part of an offence. However, Hameeuw seems to be the only one in the literature taking this stance. See: Hameeuw (n 10) 6.

${ }^{31}$ Art 3(1) Directive (EU) 2017/541 (n 4). Originally art 1.1 Council Framework Decision 2002/475/JHA (n 2). See also: Masset (n6) T60/18. Note that according to Borgers, member states were not obliged to actually include this in their definition. See: Matthias Borgers, 'Framework Decision on Combating Terrorism: Two Questions on the Definition of Terrorist Offences"' (2012) 3 New J Eur Crim L 68.

${ }^{32}$ Delhaise (n 16) 33; Ann Fransen and Jan Kerkhofs, 'Het Materieel Terrorismestrafrecht in België: De Misdrijven' (2018) 3 Tijdschrift voor Strafrecht 150, 21; Hameeuw (n 15) 6.

${ }^{33}$ Verslag namens de commissie van justitie bij wetsontwerp van 6 oktober 2003 betreffende terroristische misdrijven, Parl.St. Kamer 2003, nr. 51-0258/004, 14; De La Serna (n 16) 204-205; Delmulle and Guenter (n 16) 3; Fransen and Kerkhofs (n 32) 21.

${ }^{34}$ Art 375, section 6 CC.

${ }^{35}$ Cass. 10 maart 1930, Pas 1930, I, 156; De Nauw and Kuty (n 16) 229; Gaëlle Marlier, Familie in het straf- en strafprocesrecht: afbrokkelende hoeksteen van de samenleving? (Wolters Kluwer 2018) 299.

${ }^{36}$ Art 489-489sexies CC.

${ }^{37}$ De La Serna (n 6) 179; De La Serna (n 16) 207; Fransen and Kerkhofs (n 16) 20; Hameeuw (n 15) 5; Winants (n 6) 347.
} 
destabilizing or destroying the fundamental political, constitutional, economic or social structures of a country or an international organization'. ${ }^{38}$ This phrasing is copied from the original Framework Decision and is still part of the Directive. ${ }^{39}$ The three options are not cumulative and a political, religious or philosophical motive is not required. ${ }^{40}$ The words 'international organization' only refer to international organizations under public international law and not to NGOs for example. ${ }^{41}$ Legal theory states that the words 'a population' can refer to a nation's whole population, but to the populations of smaller areas such as a specific region or city as well. ${ }^{42}$ It does imply that the aim of intimidating a single person or very small group of people does not suffice. ${ }^{43}$ 'Government', finally, not only refers to the Belgian government, but to any government, regardless of its democratic character. ${ }^{44}$

The mens rea of terrorism stricto sensu is quite broad and vague. For example, the 'aim of seriously intimidating a population' suffices and no further goal is required. While acts of terrorism often instrumentalize fear and aim to achieve their end goals through intimidating the population ${ }^{45}$, intimidation is rarely the end goal in itself. Furthermore, terminology such as 'seriously intimidating', 'unduly compelling', 'seriously destabilizing' has an inherent vagueness about it. The broadness and vagueness of the mens rea is especially relevant because all of the terrorism offences lato sensu, which are discussed below, have a 'two stage' mens rea: their mens rea refers to terrorism stricto sensu. ${ }^{46}$ Therefore, any broadness or vagueness in the offence of terrorism stricto sensu, has an effect on the scope and delineation of all terrorist offences. Since the mens rea is a literal copy of the European instruments, it is up to the EU level to evaluate whether such broadness and vagueness is desired.

\footnotetext{
${ }^{38}$ Art 137, §1 CC. Own translation, original in Dutch and French. See also: Delhaise (n 16) 31-33; Masset (n 6) T60/18; Winants (n 6) 347.

${ }^{39}$ Art 3.2 Directive (EU) 2017/541 (n 4). Originally art 1.1 Council Framework Decision 2002/475/JHA (n 2). See also: Hameeuw (n 15) 5; Weyembergh and Kennes (n 6) 153.

${ }^{40}$ Delhaise (n 16) 31; Fransen and Kerkhofs (n 16) 20.; Hameeuw (n 15$) 6$.

${ }^{41}$ Verslag namens de commissie van justitie bij wetsontwerp van 6 oktober 2003 (n 33) 14; De La Serna (n 6) 178; De La Serna (n 16) 206; Fransen and Kerkhofs (n 16) 21; Masset (n 6) T60/18.

${ }^{42}$ De La Serna (n 6) 178; De La Serna (n 16) 206; Delhaise (n 16) 32; Fransen and Kerkhofs (n 16) 20. Hameeuw wonders where to draw the line though. When is a group of people too small to be a population? See: Hameeuw (n 15) 6.

${ }^{43}$ De La Serna (n 6) 178.

${ }^{44}$ See the GICM case: Corr. Brussel 16 Februari 2006; Brussel 19 januari 2007, Tijdschrift voor Strafrecht 2008, 281, noot F Schuermans. See as well: De La Serna, 2015 (n 16) 198-199; Fransen and Kerkhofs (n 16) 39; Weyembergh and Kennes (n 6) 159-160.

${ }^{45}$ See for example: Hoffman (n 25) 40-41; Jackson (n 25) 123; Richards, (n 25) 230.

${ }^{46}$ In addition, it sometimes refers to other terrorism offences lato sensu as well.
} 


\subsection{Offences related to terrorist groups}

\subsubsection{Terrorist groups}

Article $140 \mathrm{CC}$ contains three offences, all three of which criminalize conduct related to terrorist groups. An important question for these three offences is therefore when will a group of people become a terrorist group. Article $139 \mathrm{CC}$ defines a terrorist group as 'any structured group of more than two persons, established over a period of time and acting in concert to commit terrorist offences, as meant in Article 137.${ }^{47}$ The preparatory works further explain that a structured group is one that 'is not randomly formed and that does not need to have formally defined roles for its members, continuity of its membership or a developed structure'. ${ }^{48}$ Both these definitions are almost literal copies of an article of the Framework Decision, now Directive. ${ }^{49}$

While 'acting in concert' suggests a form of mutual deliberation and coherence of actions,${ }^{50}$ the extent of collaboration required is uncertain. For example, not all members must to be informed about each other's actions or even know each other, as long as they all contribute to the existence of the group. ${ }^{51}$ Nor does contact need to be in person, but can also be over the internet or by other means of correspondence. ${ }^{52}$

The legislature treats a terrorist group as a separate entity with its own intent, as an 'illegal entity'53. The goal of the entity must be the perpetration of terrorist offences stricto sensu. To be able to judge the goal of a certain group mainly operating in for example Syria or Iraq, sometimes a good amount of geopolitical knowledge is required. ${ }^{54}$ The situation on the ground can be chaotic and allegiances are not always clear, nor are the aims and origins of every group which is active in such areas. Furthermore, the fact that a group is part of a

\footnotetext{
${ }^{47}$ Art 139, section 1 CC. Own translation, original in Dutch and French.

${ }^{48}$ MvT bij wetsontwerp van 6 oktober 2003 betreffende terroristische misdrijven, Parl.St. Kamer 2003, nr. 510258/001, (4) 12. Own translation, original in Dutch and French. See also: Delhaise (n 16) 36-37; Hameeuw (n 15) 8; Winants (n 6) 347-348.

${ }^{49}$ Art 2 Council Framework Decision 2002/475/JHA (n 2). Now art 2.3 Directive (EU) 2017/541 (n 4). See also: De La Serna (n 6) 181-182; Delhaise (n 16) 35; Weyembergh and Kennes (n 6) 153.

${ }^{50}$ De La Serna (n 16) 211; Fransen and Kerkhofs (n 16) 28; Winants (n 6) 348.

${ }^{51}$ De La Serna (n 6) 183; De La Serna (n 16) 209-211.

${ }^{52}$ De La Serna (n 6) 183.

${ }^{53}$ In Dutch: 'strafrechtspersoon'. This term was coined by Verbruggen, in the context of criminal organizations (see: Frank Verbruggen, 'Schaduwboksen in het donker: de dogmatische onderbouw van het strafrechtelijk overheidsoptreden tegen georganiseerde criminaliteit' (PhD Thesis KULeuven, 2001) 195). Criminal organizations have a similar definition to terrorist groups (see: advies 34.362/4 van de Raad van State bij wetsontwerp van 6 oktober 2003 betreffende terroristische misdrijven, Parl.St. Kamer 2003, nr. 51-0258/001, (22) 33. See also: De La Serna (n 6) 182; Verbruggen 302-303).

${ }^{54}$ De La Serna (n 6) 184 and 201.
} 
European or international list of terrorist organizations, does not automatically mean it qualifies as a terrorist group under Article $139 \mathrm{CC}$ or vice versa. ${ }^{55}$ While the goal of the group must be the perpetration of terrorism stricto sensu, it is not required that these offences have actually been committed, or even been prepared already. ${ }^{56}$ However, how do you prove that the intent of the illegal entity is the perpetration of a terrorist attack if the preparations for the attack have not even started yet? The danger of a broad interpretation arises where groups are labelled terrorist based on vague notions that they might intend to perpetrate a terrorist attack. Given that different types of involvement in the group constitute terrorist offences (see below), this vague definition of a terrorist group can raise legality issues.

\subsubsection{Participating in the activities of a terrorist group}

\section{Actus Reus}

The terrorist offence for which by far the most prosecutions are brought is participating in the activities of a terrorist group (art. 140, $§ 1 \mathrm{CC}$ ). ${ }^{57}$ This article was also introduced in $2003^{58}$ in response to the 2002 Framework Decision ${ }^{59}$. The actus reus is the participation in any activity of a terrorist group. The Criminal Code, echoing the Directive, explicitly adds to this 'be it by providing data or material resources to a terrorist group or any form of financing of any activity of a terrorist group' ${ }^{60}$ However, this enumeration of actions is not exhaustive. ${ }^{61}$ According to Belgian case law, actions such as providing moral support, can constitute participation in the activities of a terrorist group. ${ }^{62}$ Furthermore, the contribution to the activities of the group does not need to be systematic, an occasional contribution suffices. ${ }^{63}$

\footnotetext{
55 ibid 186-187; De La Serna (n 16) 214; Fransen and Kerkhofs (n 16) 29. The council chamber and indictment chamber in Brussels for example ruled that the PKK was not a terrorist organization, even though it is on the EU list of terrorist organization. See: KI Brussel 14 september 2017, Rechtskundig Weekblad 2017-18, 1611, noot J Wouters en T Van Poecke; KI Brussel 8 maart 2019, 44; RK Brussel 3 november 2016, 11; Jan Wouters and Thomas Van Poecke, 'Van Strijdkrachten, Terroristen En Het Belgisch Strafrecht (Noot Onder KI Brussel 14 September 2017)' [2017-2018] Rechtskundig Weekblad 1616.

${ }^{56}$ De La Serna (n 6) 186; De La Serna (n 16) 212-213; Delhaise (n 16) 38; Fransen and Kerkhofs (n 16) 29; Hameeuw (n 15) 8; Winants (n 6) 348.

${ }^{57}$ Fransen and Kerkhofs (n 16) 16; Winants (n 6) 349.

${ }^{58}$ Art 6 wet van 19 december 2003 betreffende terroristische misdrijven, $B S 29$ december 2003, 61689.

${ }^{59}$ Art 2 Council Framework Decision 2002/475/JHA (n 2). Now art 4 Directive (EU) 2017/541 (n 4).

${ }^{60}$ Art 140, §1 CC. Own translation, original in Dutch and French.

${ }^{61}$ MvT bij wetsontwerp van 6 oktober 2003 (n 48) 13; Corr. Brussel 3 mei 2016, 35; De La Serna (n 6) 191.

${ }^{62}$ Brussel 2 juni 2017, 22; Corr. Brussel 3 mei 2016, 36; Corr. Brussel 8 mei 2017, 5; Fransen and Kerkhofs (n 16) 32; Fransen and Kerkhofs (n 32) 159; Ward Yperman and Sofie Royer, 'Veroordeling Jihadibruid' [2017] Nieuw Juridisch Weekblad 813.

${ }^{63}$ MvT bij wetsontwerp van 6 oktober 2003 (n 48) 13; De La Serna (n 6) 191; De La Serna (n 16) 219; Delhaise (n 16) 40; Fransen and Kerkhofs (n 16) 30; Hameeuw (n 15) 9.
} 
The case law has given a broad interpretation of participation in any activity of a terrorist group despite Article 140, $§ 1 \mathrm{CC}$ requiring a concrete act of participation. This interpretation includes following military training with a terrorist group ${ }^{64}$, or fighting for a terrorist group in a war zone ${ }^{65}$, but also sending a package of (civilian) clothes to a family member who is a member of a terrorist group ${ }^{66}$, cooking or being a driver for the group ${ }^{67}$, mentally encouraging fighters of the group by sending them messages from their families or promising them to join them ${ }^{68}$ and marrying and having a sexual relationship with a fighter of the group ${ }^{69}$. This very wide interpretation results in Article $140, \S 1 \mathrm{CC}$ having a very wide potential scope of application. One would thus expect the mens rea to narrow down the scope of application of the article. ${ }^{70}$

\section{Mens Rea}

This mens rea is: 'he knew or should have known that his participation could contribute to the committal of a felony or standard offence by the terrorist group'. ${ }^{71}$ This felony or standard offence does not necessarily have to be a terrorist offence, any felony or standard offence suffices. ${ }^{72}$ Nor does the connection to the committal of the offence by the group have to be a direct one. ${ }^{73}$ The person also does not have to have the intention of committing this offence himself. ${ }^{74}$ Committing offences is the intention of the illegal entity but not necessarily of the individual people participating in its activities.

Following the introduction of the Article 140 in 2003, the mens rea was 'he knows that his participation contributes to the committal of a felony or standard offence by the terrorist

\footnotetext{
${ }^{64}$ Brussel 28 mei 2015, 29.

${ }^{65}$ Corr. Brussel 3 mei 2016, 52.

${ }^{66}$ Corr. Brussel 14 mei 2014.

${ }^{67}$ Corr. Antwerpen (afd. Antwerpen) 11 februari 2015, 50; Corr. Antwerpen 30 maart 2015, 4; Corr. Antwerpen (afd. Antwerpen) 25 januari 2016, 3.

${ }^{68}$ Corr. Brussel 3 mei 2016, 38-39.

${ }^{69}$ Corr. Oost-Vlaanderen (afd. Gent) 16 oktober 2017, Nieuw Juridisch Weekblad 2017, 805, noot W Yperman en S Royer.

${ }^{70}$ Stéphanie De Coensel, 'Counter-Terrorism \& Criminal Law: A Normative Legitimacy Test of TerrorismRelated Offences on Expression, Information and Movement' (PhD Thesis, University of Ghent 2020) 271.

${ }^{71}$ Art 140, 11 CC. Own translation, original in Dutch and French.

${ }^{72}$ MvT bij wetsontwerp van 6 oktober 2003 (n 48) 13; De La Serna (n 6) 189; De La Serna (n 16) 216; Fransen and Kerkhofs (n 16) 30; Hameeuw (n 15) 9; Winants (n 6) 348.

${ }^{73}$ MvT bij wetsontwerp van 6 oktober 2003 (n 48) 13; Delhaise (n 16) 40-41; Delmulle and Guenter (n 16) 4; Fransen and Kerkhofs (n 16) 30.

${ }^{74}$ De La Serna (n 6) 189; Delhaise (n 16) 42-43.
} 
group'. ${ }^{75}$ This was copied from the Framework Decision and the Directive is still worded similarly. ${ }^{76}$ In December 2016, however, the Belgian legislature chose to be more restrictive and changed the wording to the current one. ${ }^{77}$ This is remarkable since at the introduction of the article in 2003, the explanatory memorandum stated that knowing that a person contributes to the committal of felonies and standard offences by the terrorist group was the decisive criterion. ${ }^{78}$ The change was made with the Dutch concept of 'mogelijkheidsbewustzijn'79 in mind. ${ }^{80}$ 'Mogelijkheidsbewustzijn' is present when somebody intentionally acts or fails to act, while knowing a consequence (which he does not intend) is possible, but he does not let this possibility stop him. He accepts the possible consequences. ${ }^{81}$ This closely resembles the Belgian concept of potential intent. ${ }^{82}$

This standard is more flexible than Belgian general intent ('knowingly and willingly') in two ways. First, the knowledge element ('knowingly') is relaxed to knowledge of the possibility of consequences instead of certainty. Second, the will element ('willingly') is relaxed to accepting the consequences instead of actually wanting them. ${ }^{83}$ If we look at both changes to the mens rea separately, we see that the second change ('could contribute') is indeed a part of 'mogelijkheidsbewustzijn'/potential intent: the knowledge element is being relaxed to knowledge of the possibility. The first change ('should have known'), by contrast, is a

\footnotetext{
${ }^{75}$ MvT bij wetsontwerp van 6 oktober 2003 (n 48) 13. Own translation, original in Dutch and French. See also: Fransen and Kerkhofs (n 16) 28; Winants (n 6) 348.

${ }^{76}$ Art 4 (b) Directive (EU) 2017/541 (n 4).

${ }^{77}$ Art 2 wet van 14 december 2016 tot wijziging van het Strafwetboek wat betreft de bestraffing van terrorisme, BS 22 december 2016, 88017.

${ }^{78}$ MvT bij wetsontwerp van 6 oktober 2003 (n 48) 7; Weyembergh and Kennes (n 6) 154; Winants (n 6) 348.

${ }^{79}$ Which literally translates to opportunity awareness. Another term for it can be translated as 'conditional intent'.

${ }^{80}$ Toelichting bij wetsvoorstel van 13 januari 2016 tot wijziging van het Strafwetboek wat betreft de bestraffing van terrorisme, Parl.St. Kamer 2015-16, nr. 54-1579/001, 3; Fransen and Kerkhofs (n 16) 35; Winants (n 6) 355.

${ }^{81}$ Conclusie A-G Berger bij Hoge Raad 30 mei 1975, ECLI:NL:PHR:1975:AC5594 (bierglasarrest). See also: Gerechtshof Den Haag 27 oktober 2016, ECLI:NL:GHDHA:2016:3699; AC 'T Hart, noot onder Hoge Raad 15 oktober 1996, ECLI:NL:HR:1996:ZD0139; AJ Machielsen, 'Materiële verweren', in MF Attinger et al (eds), Handboek Strafzaken (Wolters Kluwer 2018) 36.1.1.1.

${ }^{82}$ Lieven Dupont, Beginselen van Strafrecht, Deel I (Acco 1983) 184; V Vereecke, 'Het eventueel opzet bij de beoordeling van het oogmerk om te doden' [2019] Rechtspraak Antwerpen Brussel Gent 25, 26-27.; J De Groote, 'De bovengrens der fout en de ondergrens van het opzet met bijzondere aandacht voor het eventueel opzet: een doctrinale en rechtsvergelijkende analyse' [2017] Nullum Crimen special number April 2017, 66, 75-79; B Ketels, 'De strafrechtelijke context van risicovol seksueel gedrag' [2008] Tijdschrift voor Strafrecht 354, 361; J Verhaegen, 'Le dol éventuel et sa place en droit pénal belge' in X (ed), Liber Amicorum Hermann Bekaert (Snoeck-Ducaju \& Zoon 1977) 437, 441-442.

${ }^{83}$ Dupont states that potential intent is a weakening of the knowledge element and Vereecke states that it is a weakening of the will element. In my opinion both are correct and both elements are weakened.
} 
relaxation of the knowledge element nor of the will element. The Council of State described it as a 'potential knowing' instead of a 'real knowing'. ${ }^{84}$

This 'potential knowing' can only be deduced from concrete elements of the file and not from abstract criteria. ${ }^{85}$ It is a way to prove intent rather than a form of intent, a type of 'he should have known so he knew'-reasoning. ${ }^{86}$ If we combine both changes, we have a relaxation of the knowledge element and a rule of evidence. Although potential intent is a form of general intent, the relaxation of the knowledge element it entails, is not without danger in this context. The concept 'contributing to the commission of a felony or standard offence by the group' is an abstract one in any case and further relaxing the knowledge element to 'could contribute' makes it even more abstract and thus more vague.

The actus reus of the offence is so broad it can encompass nearly any action and the mens rea is very broad and vague as well. As a result, people who in any way support a member of a terrorist group, without supporting the group itself and without wanting their actions to contribute to the committal of a felony or standard offence by the group, are being convicted anyway. Support to a member of the group is being fully equated to support to the group itself. ${ }^{87}$ This is regrettable because many of those people may not be supporters of a terrorist group. They could simply be people who want to help their brother, son or lover, even though the latter have made very questionable choices. Employing the criminal justice system against a person whose only action is sending some clothes to their brother is not the best solution to say the least. All this leads to a legality issue: it grants very wide discretion to the judge and creates uncertainty in the minds of the person committing these actions about whether they are committing an offence. ${ }^{88}$ Therefore, the wording of the mens rea should be limited again to what is required by the Directive and the courts should require an actual link between the act of participation and the committal of a felony or standard offence by the group. These changes

\footnotetext{
${ }^{84}$ Advies 59.789/3 van de Raad van State bij wetsvoorstel van 2 augustus 2016 tot wijziging van het Strafwetboek wat betreft de bestraffing van terrorisme, Parl.St. Kamer 2015-16, nr. 54-1579/006, 8.

${ }^{85}$ Ibid 9; Fransen and Kerkhofs (n 16) 35; Winants (n 6) 355.

${ }^{86}$ De Groote (n 82) 96-97; W Devroe and A Rombouts, 'Wissel als witsel. De beteugeling van het witwassen van gelden via geldwissel in het Belgisch financieel en strafrecht (noot onder corr. Antwerpen 23 februari 1993)' [1994] TRV 199, 204.

${ }^{87}$ This reduces a person to one aspect of their identity: that of member of the group. However, it could be sensible to emphasise other aspects of their identity (father, brother, etc.) which are not shared with the group, in order to make them break away from the group. If all 'healthy contacts' of a member of a terrorist group are being forced to keep a distance under threat of criminal action, the group member only has the group and its sympathisers to fall back on. This just strengthens their bond with the group and their break with the rest of society.

${ }^{88}$ Advies 59.789/3 van de Raad van State (n 84) 7.
} 
would bring the Belgian legislation back in line with the Directive and reduce the scope of the offence.

\subsubsection{Participating in the making of any decision regarding the activities of a terrorist organization}

The 2019 statute introduced a new paragraph to Article 140 CC. It was placed in between $\S 1$ and $\S 2$, creating an intermediate offence. ${ }^{89}$ This was intended to provide the courts with more options when assessing the broad spectrum of activities covered by Article 140, $§ 1$ $\mathrm{CC}$ by upgrading some activities into a higher sentencing bracket. As an intermediate offence, Article 140, $§ 1 / 1 \mathrm{CC}$ punishes the participation in the taking of any decision in the context of the activities of the terrorist group..$^{90}$ This offence is not part of the Directive. The Belgian legislature was inspired by the pre-existing Belgian offences concerning the criminal organization. $^{91}$

In the context of the offence of participating in the making of any decision in the framework of the activities of a criminal organization, Verbruggen states that 'making any decision' is not a suitable actus reus for an offence. ${ }^{92}$ We make a plethora of decisions every single day, making the criterion of 'participating in the making of any decision' void. The same criticism can be levelled against A140, $§ 1 / 1$ CC. Deciding what to drink during a meeting, whether or not to open the window, where to sit, etc. Those are all decisions, which will lead a person to commit this offence when they are made in the context of the activities of a terrorist group. Since making a decision is almost inevitable, anyone who came within the ambit of the offence of participating in the activities of the group, will now come within the ambit of this offence. As we have seen, this is a very broad category of people. The man who sent clothes to his brother the terrorist fighter decided to send those clothes, the woman who married the terrorist fighter decided to marry him, etc. Furthermore, not only making decisions is punishable, but also participating in the making of a decision. This means that a member of the group who voted against committing a terrorist attack falls under this offence. Even an outsider, non-member, who tries to convince his friend who is a member of a group not to do something stupid, is participating in the making of this decision. Therefore, it is clear the offence is too

\footnotetext{
${ }^{89}$ Toelichting bij wetsvoorstel van 6 februari 2019 (n 8) 102-103; De Coensel (n 21) 214; Winants (n 6) 357.

${ }^{90}$ Art 75 wet van 5 mei 2019 (n 21).

${ }^{91}$ Art 324ter, §3 CC; Toelichting bij wetsvoorstel van 6 februari 2019 (n 8) 102-103; De Coensel (n 21) 214; Winants (n 6) 357.

92 Verbruggen (n 53) 347-348.
} 
broad. While the legislature attempted to create an offence which targets members of terrorists organizations higher up the ladder, it created one with an actus reus which is almost as broad as the offence of participating in the activities of the group. This offence with its exceedingly broad actus reus, which is not part of the Directive, runs afoul of the legality principle and the legislature would do well to delete it again.

\subsubsection{Leadership of a terrorist organization}

The second paragraph of Article $140 \mathrm{CC}$ criminalizes leadership of a terrorist group. While the Directive imposes on member states the obligation to criminalize directing a terrorist group, the definition of leadership and directing is ambiguous. The preparatory works of the Belgian statute define leaders as 'the people who take upon themselves the more important responsibilities within the group'. ${ }^{93}$ Further, leaders are 'because of their central role within the terrorist group, better informed than anyone about the offences and take the final decisions'. ${ }^{94}$ The Council of State thought that the legislature should clarify the article so that it reflected this intention more clearly. ${ }^{95}$ Despite this advice, the legislature decided not the change the article. With the introduction of the offence in $\S 1 / 1$, the question now also arises as to what the difference is between a final decision (taken by a leader) and any other decision. The offence of leadership does not require that the person himself had the intention of committing a terrorist offence or that he was involved in committing it. ${ }^{96}$ Nor does it require that the person is the leader of the entire group. Having a central role, being able to speak for the group, coordinating actions, raising funds, etc. suffices. ${ }^{97}$ The size and importance of the group are irrelevant as well, so long as it is a terrorist group..$^{98}$

In practice, the jurisprudence interprets 'leadership' quite broadly. For example, the court of appeal in Antwerp found that it entails close involvement in several meetings, and not excluding that one would commit an attack himself. ${ }^{99}$ The fact that two other people were designated as respectively leader of the cell and spiritual leader, did not change this. The court

\footnotetext{
${ }^{93}$ MvT bij wetsontwerp van 6 oktober 2003 (n 48) 14. Own translation, original in Dutch and French.

${ }^{94}$ Ibid. Own translation, original in Dutch and French. See also: De La Serna (n 16) 215; Fransen and Kerkhofs (n 16) 35-36; Winants (n 6) 348.

95 Advies 34.362/4 van de Raad van State (n 53) 40-41.

${ }^{96}$ Cass. 24 juni 2008, Arr. Cass. 2008, 1654; De La Serna (n 6) 188; De La Serna (n 16) 215-216; Delhaise (n 16) 44; De Nauw and Kuty (n 16) 18.

${ }^{97}$ De La Serna (n 6) 187-188; De La Serna (n 16) 215; Delhaise (n 16) 41; Fransen and Kerkhofs (n 16) 37; Winants (n 6) 348.

${ }^{98}$ Winants (n 6) 348.

${ }^{99}$ Antwerpen 8 januari 2014, 42.
} 
of appeal in Brussels, in turn, convicted a person for leadership who provided material support to terrorist fighters in Syria (who were departing or already on-site), who was an intermediary and facilitated communication between jihadists ${ }^{100}$, jihadist candidates and their families, and who was an advisor when it came to indoctrination and exfiltration to Syria. ${ }^{101}$ Clearly these actions make them active members of the group, but not necessarily leaders. The ambiguity of this definition is also evidenced by the court of appeal's jurisprudence which frequently overturns convictions for participation and converts them into leadership and vice versa. ${ }^{102}$ This is caused by the lacking definition of leadership in Article 140, $\$ 2 \mathrm{CC}$, and indicates that the legislature should have implemented the advice of the Council of State. The Belgian legislature was also not helped by the Directive, which does not define 'directing' either.

\subsection{Public provocation to commit terrorism}

\subsubsection{Actus Reus}

Article 140bis CC was introduced in 2013, in response to the Council of Europe Convention on the Prevention of Terrorism ${ }^{103}$ and the Council Framework Decision 2008/919/JHA ${ }^{104}$. It is currently included in Article 5 of the Directive. Since its introduction into Belgian law, the actus reus of the offence was the following: disseminating or otherwise making available to the public a message when such conduct, whether or not directly aimed at the commission of terrorist offences, carries a risk that one or more of these offences may be committed. Evidently, the Belgian legislature criminalized both direct and indirect incitement to commit a terrorist offence. ${ }^{105}$ The general rules on public incitement, which are applicable to all felonies and standard offences, only criminalize direct incitement. ${ }^{106}$

Several factors are important for the analysis of whether or not there is a risk that terrorist offences may be committed. These factors are: the perpetrator (e.g. whether he is a person of influence and charisma), the receiver (e.g. the amount of people who receive the message and how easy they are to influence), the nature of the message (e.g. whether the words

\footnotetext{
${ }^{100}$ In this case it concerned people who traveled to Syria to join Majlis Shura al-Mujahideen, Jabbat Al-Nusra and/or Islamic State.

${ }^{101}$ Brussel 2 juni 2017, 26-30.

${ }^{102}$ Brussel 19 januari 2007, Tijdschrift voor Strafrecht 2008, 281; Antwerpen 8 januari 2014; Brussel 18 november 2016; Brussel 31 maart 2017.

${ }^{103}$ Art 5 Council of Europe Convention (n 1).

${ }^{104}$ Council Framework Decision 2008/919/JHA (n 3).

${ }^{105}$ MvT bij wetsontwerp van 13 november 2012 (n 7) 11; Delhaise (n 16) 48; Winants (n 6) 350.

${ }^{106}$ Art 66 CC; MvT bij wetsontwerp van 13 november 2012 (n 7) 11.
} 
themselves call for violence or hatred) and the context (e.g. political tension). ${ }^{107}$ In the original bill, the risk that one or more terrorist offences is committed was not required. ${ }^{108}$ However, the Council of State pointed out that this risk requirement was part of the European instruments and that omitting it might lead the offence to violate the freedom of expression. ${ }^{109}$ Thus, the legislature amended the bill to remedy this issue, stating that:

it is imperative to specify that the criminalization of public incitement to commit terrorist acts must not lead to the punishment of acts which have no connection whatsoever with terrorism and would thus create the danger of restricting the freedom of expression. Therefore, it is important to stress that these offences may only be aimed at those situations in which there are serious indications that a danger exists that a terrorist offence would be committed. ${ }^{110}$

However, in 2016 the legislation was amended again. The legislature vaguely referred to the altered security situation, the foreign terrorist fighter problem and the role of social media in radicalization, to delete the risk requirement because it was too difficult to prove. ${ }^{111}$

When Article 140bis CC was initially introduced into the Criminal Code in 2013, an appeal for annulment was filed with the Constitutional Court. One of the arguments made for annulment was based on freedom of expression. The Constitutional Court stated that freedom of expression is one of the pillars of a democratic society and therefore exceptions need to be interpreted strictly. ${ }^{112}$ Thus, Article 140bis CC must comply with Article 10.2 ECHR. ${ }^{113}$

It follows that the legislature must demonstrate that the restrictions are necessary in a democratic society, that they correspond to an overriding societal need and that they remain proportionate to the legitimate objectives they pursue. ${ }^{114}$ The Court stated that it is necessary to protect society against those who would undercut it through violence and terrorism. ${ }^{115}$ The

${ }^{107}$ MvT bij wetsontwerp van 13 november 2012 (n 7) 12-13. Delhaise (n 16) 51; Fransen and Kerkhofs (n 16) 52-53; Winants (n 6) 350.

${ }^{108}$ MvT bij wetsontwerp van 13 november 2012 (n 7) 19-20; Velaers (n 1) 779; Winants (n 6) 354.

${ }^{109}$ Advies 51.806/3 van de Raad van State bij wetsontwerp van 13 november 2012 tot wijziging van Titel 1ter van het Strafwetboek, Parl.St. Kamer 2012-13, nr. 53-2502/001, (22) 25-27; Velaers (n 1) 779; Winants (n 6) 354.

${ }^{110}$ MvT bij wetsontwerp van 13 november 2012 (n 7) 12. Own translation, original in Dutch and French.

${ }^{111}$ MvT bij wetsontwerp van 6 juli 2016 houdende diverse bepalingen ter bestrijding van terrorisme (III), Parl.St. Kamer 2015-16, nr. 54-1951/001, (4) 8; De Coensel (n 70) 184; Delhaise (n 16) 49; Fransen and Kerkhofs (n 16) 51 ; Winants (n 6) 353-354.

${ }^{112} \mathrm{GwH} 28$ januari 2015, 9/2015, TVW 2015, 179, B.24.

${ }^{113}$ Ibid B.25.3.

${ }^{114} \mathrm{Ibid}$ B.24 and B.25.3.

${ }^{115}$ Ibid B.25.4. 
government may limit freedom of expression to attain that goal. The legislature had stated it did not aim to punish actions that are not connected to terrorism. This, in combination with the special intent required and the fact that the judge needs to take into account the person who spreads the message, the person who receives it, and the nature and the context of the message, makes that although the judge has a wide margin of appreciation, Article 140bis CC does not violate the freedom of expression. ${ }^{116}$

After the deletion of the risk requirement, however, the article was brought before the Constitutional Court again. The Court made the same analysis of restrictions to the freedom of expression. Yet, this time the Court's conclusion was that Article 140bis CC did violate the freedom of expression and the article deleting the risk requirement was annulled. ${ }^{117}$ The need to facilitate the proof of the offence does not justify the imposition of an imprisonment and fine when there are no serious indications that there is a risk of a terrorist offence. Therefore, Article 140bis CC, without the risk requirement is not necessary in a democratic society and limits the freedom of expression unduly. ${ }^{118}$ In closing, the Court remarks that both the Framework Decision and the Directive include such a risk requirement. ${ }^{119}$ Because of the annulment of the part of the article that deleted the risk requirement, the risk requirement was revived and is part of Article 140bis CC again.

The Criminal Code criminalizes the dissemination or otherwise making available of a message to the public. This implies a positive action and refraining from undertaking a certain action can therefore not suffice. ${ }^{120}$ In order to be punishable, the incitement does not have to be aimed at a specific person or group of people (intuitu personae). ${ }^{121}$ Therefore, incitement can easily happen over the internet as well, as long as it is public. ${ }^{122}$ Any mode of dissemination can be punishable. ${ }^{123}$ The message has to be made available to the public, which means that one conversation between two people is probably not covered. ${ }^{124}$ According to the case law, however, even individual messages to people can be public because the internet allows them

\footnotetext{
116 Ibid B.25.4-B.25.5.

${ }^{117}$ GwH 15 maart 2018, 31/2018, Nieuw Juridisch Weekblad 2018, 477, B.8. See also: De Coensel (n 70) 184; Fransen and Kerkhofs (n 16) 53-54; Winants (n 6) 354.

118 GwH 15 maart 2018, 31/2018, Nieuw Juridisch Weekblad 2018, 477, B.7.6. See also: Delhaise (n 16) 49; Winants (n 6) 354; Ward Yperman, 'Terro III dan toch een stap te ver' [2018] Nieuw Juridisch Weekblad 480.

119 GwH 15 maart 2018, 31/2018, Nieuw Juridisch Weekblad 2018, 477, B.7.7. See also: Delhaise (n 16) 50; Winants (n 6) 354

${ }^{120}$ Delhaise (n 16) 50.

${ }^{121}$ Fransen and Kerkhofs (n 16) 55; Winants (n 6) 350.

${ }^{122}$ MvT bij wetsontwerp van 13 november 2012 (n 7) 13; Fransen and Kerkhofs (n 16) 55; Winants (n 6) 350

${ }^{123}$ Delhaise (n 16) 50.

124 ibid 50-51.
} 
to spread and multiply quickly. ${ }^{125}$ In addition, the incitement does not have to be aimed at the committal of a concrete offence. ${ }^{126}$ Nor does the incited offence actually have to take place. ${ }^{127}$

\subsubsection{Mens Rea}

A special intent is required, being 'the intention of inciting the commission of one of the offences referred to in Article 137 or 140sexies, with the exception of the offence referred to in Article 137, $\S 3,6^{\circ},{ }^{128}$ The article thus refers to terrorism stricto sensu, with the exception of threatening a terrorist offence, and the offence of traveling for terrorist purposes (see below). This corresponds to the Directive, except for traveling, which is not part of the mens rea in the Directive. It was not part of the original mens rea in Belgian law either, since the offence did not exist yet in 2013, but was added in 2016. ${ }^{129}$ In doing so, the Belgian legislature took a more repressive approach than the Directive. Since the traveling offence has a very broad mens rea itself (see below), the mens rea of Article 140bis CC is broad too, and significantly broader than the Directive's. In 2016 the legislature also added the words 'directly or indirectly' after the word intention because when deleting the risk requirement, they also deleted the reference to indirect incitement. To clarify that the offence included indirect incitement, the legislature explicitly inserted it into the mens rea. ${ }^{130}$ However, after the Constitutional Court judgment, which reinstated the risk requirement, this idea of 'direct or indirect incitement' was part of the offence twice. ${ }^{131}$ Therefore, the legislature deleted it from the mens rea again in $2019 .{ }^{132}$

\subsection{Terrorist recruitment}

\subsubsection{Actus Reus}

Article 140ter CC criminalizes recruitment for terrorist purposes. It was also introduced in 2013, in the wake of the Council of Europe Convention and the update of the Framework Decision and is now Article 6 of the Directive. ${ }^{133}$ The article criminalizes anybody who recruits

\footnotetext{
${ }^{125}$ Corr. West-Vlaanderen (afd. Brugge) 26 juli 2018, 10; Fransen and Kerkhofs (n 16) 60-61.

${ }^{126}$ Delhaise (n 16) 52; Fransen and Kerkhofs (n 16) 55-56; Winants (n 6) 350.

127 Amendement nr. 1 bij wetsvoorstel van 13 januari 2016 tot wijziging van het Strafwetboek wat betreft de bestraffing van terrorisme, Parl.St. Kamer 2015-16, nr. 54-1579/005, 6; Winants (n 6) 350.

${ }^{128}$ Art 140bis CC. Own translation, original in Dutch and French. See also: MvT bij wetsontwerp van 13 november 2012 (n 7) 13; Delhaise (n 16) 52; Fransen and Kerkhofs (n 16) 56; Winants (n 6) 350.

${ }^{129}$ MvT bij wetsontwerp van 6 juli 2016 (n 111) 7; Delhaise (n 16) 49; Fransen and Kerkhofs (n 16) 51.

${ }^{130}$ MvT bij wetsontwerp van 6 juli 2016 (n 111) 8; Delhaise (n 16) 49; Fransen and Kerkhofs (n 16) 57.

${ }^{131}$ Fransen and Kerkhofs (n 16) 54-55; Winants (n 6) 354; Yperman, 'Terro III dan toch een stap te ver' (n 118).

${ }^{132}$ Art 76 wet van 5 mei 2019 (n 21); Toelichting bij wetsvoorstel van 6 februari 2019 (n 8) 103; Winants (n 6) 357.

${ }^{133}$ Art 6 Council of Europe Convention (n 1); Council Framework Decision 2008/919/JHA (n 3); MvT bij wetsontwerp van 13 november 2012 (n 7) 14.
} 
another person to commit or contribute to the commission of one of the offences in Article 137, 140 or 140 sexies CC, with the exception of Article $137, \S 3,6^{\circ} \mathrm{CC}$. So this is terrorism stricto $s e n s u$, with the exception of threatening terrorism, the offences relating to terrorist groups, and traveling for terrorist purposes. ${ }^{134}$ This matches the Directive, with the exception of traveling, which was added by the Belgian legislature in 2016 when the traveling offence was created. ${ }^{135}$ The part reading 'or contribution to the commission', was added in $2019,{ }^{136}$ as it was included in the Directive, but not yet in the Belgian legislation. ${ }^{137}$ If necessary, these actions could be prosecuted under Article $140 \mathrm{CC}$ or as aiding and abetting. ${ }^{138}$ However, since 2016 this phrase was part of the offence in Article $141 \mathrm{CC}$ (see below) and to maintain uniformity, the legislature decided to also introduce it into Article 140ter CC. ${ }^{139}$ This addition maintained uniformity at the cost of increased overlap. There will be very few situations of recruiting a person to contribute to the commission of a terrorist offence, which are not covered by Article $140 \mathrm{CC}$. This situation will always involve three people (the recruiter, the contributor to the ultimately intended offence and its perpetrator) and three people is the threshold for a terrorist group. Even if there is no terrorist group, the rules on aiding and abetting apply both to the recruitment offence and to the ultimately intended terrorist offence. Instead of criminalizing new situations, the addition of this phrase predominantly brought situations within the ambit of this offence which were already covered by other terrorist offences, therefore reducing clarity and simplicity.

An exact definition of recruitment has not been provided by the legislature. In the context of human trafficking, the Court of Cassation has stated that recruitment needs to be understood in its normal meaning. ${ }^{140}$ Hence, enlisting people or getting someone to join a group is recruitment. ${ }^{141}$ For the offence of recruitment to take place, it is not required that the recruited person actually commits one of the offences he was recruited for. ${ }^{142}$ What is required, is that

\footnotetext{
${ }^{134}$ Delhaise (n 16) 55; Fransen and Kerkhofs (n 16) 61; Winants (n 6) 351.

${ }^{135}$ Art 3 wet van 3 augustus 2016 houdende diverse bepalingen ter bestrijding van terrorisme (III), BS 11 augustus 2016, 50973; Fransen and Kerkhofs (n 16) 62; Winants (n 6) 353.

${ }^{136}$ Art 77, $1^{\circ}$ wet van 5 mei 2019 (n 21); De Coensel (n 21) 212.

${ }^{137}$ Art 6 Directive (EU) 2017/541 (n 4); Winants (n 6) 357.

138 Toelichting bij wetsvoorstel van 6 februari 2019 (n 8) 104.

139 Ibid 104-105.

${ }^{140}$ Cass. 8 oktober 2014, P.14.0955.F.

${ }^{141}$ Delhaise (n 16) 55.

${ }^{142}$ MvT bij wetsontwerp van 13 november 2012 (n 7) 14; Amendement nr. 1 bij wetsvoorstel van 13 januari 2016 (n 127) 6; Delhaise (n 16) 55; Fransen and Kerkhofs (n 16) 61; Winants (n 6) 351.
} 
the recruiter successfully approaches the other person, meaning he convinced him to perpetrate the offence. ${ }^{143}$

\subsubsection{Mens Rea}

Article 140ter CC does not explicitly include a mens rea. However, this does not mean there is no mens rea. ${ }^{144}$ Belgian criminal law always requires both actus reus and mens rea. ${ }^{145}$ The Directive states the offence must be committed intentionally. However, since the Belgian legislation requires special intent for nearly all terrorist offences, it would be logical to also require special intent. It is therefore generally accepted that 'recruitment to commit' one of the offences mentioned above, means 'recruitment with the aim of seeing one of these offences being committed'. ${ }^{146}$ This is form of special intent. As was explained above, the traveling offence was added to the mens rea in 2016, expanding it beyond the scope of offence in the Directive. The Belgian offence is therefore broader, and vaguer than the one in the Directive.

\subsection{Providing training for terrorism}

\subsubsection{Actus Reus}

For both the actus reus and mens rea of this offence (Article 140quater CC), the Belgian legislature passed wording very similar to the European instruments. ${ }^{147}$ The actus reus is to instruct or provide training in the manufacturing or use of explosives, firearms or other weapons or harmful or dangerous substances or in other specific methods and techniques. ${ }^{148}$ This is a non-exhaustive list, so any training or instruction that is provided with the required mens rea can fall within the scope of this article. For example, flying or driving lessons, or lessons on how to hack a website, can all constitute training in the sense of Article 140quater

\footnotetext{
${ }^{143}$ MvT bij wetsontwerp van 13 november 2012 (n 7) 14; Fransen and Kerkhofs (n 16) 61; Winants (n 6) 351. Delhaise talks about the proposal being received ("la proposition du recruteur est accueillie par la personne approchée' (Delhaise (n 16) 55.)).

${ }^{144}$ Cass. 12 mei 1987, AR728, Arr.Cass. 1986-87, 1194; Cass. 13 december 1994, P.94.0736.N, Arr.Cass. 1994, 1104; Damien Vandermeersch, Eléments de droit pénal et de procédure pénale (die Keure / la Charte 2015) 166172.

${ }^{145}$ Winants (n 6) 359.

${ }^{146}$ Delhaise (n 16) 56; Fransen and Kerkhofs (n 16) 62-63; Winants (n 6) 351.

147 Art. 7 Directive (EU) 2017/541 (n 4). See also: Fransen and Kerkhofs (n 16) 64.

${ }^{148}$ Art 140quater CC.
} 
CC. ${ }^{149}$ The training provided can be theoretic or practical. ${ }^{150}$ Both 'instruct' and 'provide' imply an action on behalf of the perpetrator. ${ }^{151}$

\subsubsection{Mens Rea}

The mens rea is a special intent, being: with a view to commit or contribute to the commission of one of the offences referred to in Article 137, with the exception of the offence referred to in Article 137, $\$ 3,6^{\circ} \mathrm{CC} .{ }^{152}$ So the training has to be provided with the view to commit or contribute to the commission of terrorism stricto sensu, once more with the exception of threatening a terrorist attack. Here too, the part 'or contribute to the commission of' was added in $2019^{153}$, because this is part of the wording of the Directive and the legislature wanted to increase coherence. ${ }^{154}$ Concreteness is not required, so the person providing the training does not need to know the exact terrorist offence for which he is providing training. ${ }^{155}$

\subsection{Receiving training for terrorism or self-study}

\subsubsection{Actus Reus}

Together with the offence of providing instruction or training, the legislature introduced the offence of receiving training for terrorism, ${ }^{156}$ stating that it made operational and logical sense to also criminalize the person who receives the training. ${ }^{157}$ The wording of this offence also closely resembles that of the Directive. ${ }^{158}$ Article 140 quinquies CC criminalizes anybody who, in Belgium or abroad, receives instruction or training as described in Article 140quater CC. The article explicitly refers to Article 140quater CC regarding the type of instruction or training, so anything said there is also applicable here. ${ }^{159}$

In 2019, the legislature added a new section to Article 140quinquies CC. ${ }^{160}$ This section contains a second offence. The actus reus of this offence is: in Belgium or abroad, acquiring

\footnotetext{
${ }^{149}$ MvT bij wetsontwerp van 13 november 2012 (n 7) 15; Fransen and Kerkhofs (n 16) 64; Winants (n 6) 351.

${ }^{150}$ Delhaise (n 16) 58.

151 ibid 57.

${ }^{152}$ Art 140quater CC; MvT bij wetsontwerp van 13 november 2012 (n 7) 15; Delhaise (n 16) 58; Fransen and Kerkhofs (n 16) 65.

${ }^{153}$ Art 78, $1^{\circ}$ wet van 5 mei 2019 (n 21); De Coensel (n 21) 212.

${ }^{154}$ Art 7 Directive (EU) 2017/541 (n 4); Toelichting bij wetsvoorstel van 6 februari 2019 (n 8) 104-105; Winants (n 6) 357.

${ }^{155}$ Delhaise (n 16) 58 and 78; Fransen and Kerkhofs (n 16) 65; Winants (n 6) 351.

${ }^{156}$ Art 7 wet van 18 februari 2013 (n 19).

${ }^{157}$ MvT bij wetsontwerp van 13 november 2012 (n 7) 16; Fransen and Kerkhofs (n 16) 67.

${ }^{158}$ Art. 8 Directive (EU) 2017/541 (n 4).

${ }^{159}$ Delhaise (n 16) 60; Winants (n 6) 351.

${ }^{160}$ Art $79,2^{\circ}$ wet van 5 mei 2019 (n 21).
} 
knowledge yourself or educating yourself in the matters referred to in Article 140quater CC. Due to the wording of the first section, it is generally accepted that its scope only covers people receiving training from somebody else. ${ }^{161}$ As the considerations to the Directive state that training should also include self-study ${ }^{162}$, the legislature decided to introduce this second section specifically targeting self-study. ${ }^{163}$ In the preparatory works, the legislature emphasizes that occasionally visiting a website, or visiting it for academic purposes does not suffice to be punishable. There needs to be an active and conscious action of the perpetrator. ${ }^{164}$

Both sections explicitly state that the training is received or undertaken in Belgium or abroad. ${ }^{165}$ This is not specified in the offence of providing training, nor in many of the other terrorist offences. It is unclear why the legislature decided to specify this in Article 140quinquies CC. ${ }^{166}$ It is highly unlikely that the Belgian legislature intended to imply that the other offences, such as providing training, are not punishable if they did not take place on Belgian soil. As imposed by the Directive ${ }^{167}$, the Belgian legislation includes grounds of extraterritorial jurisdiction for terrorism. ${ }^{168}$ Furthermore, in one of the examples in the preparatory works of Article 140quater explicitly refers to training provided abroad. ${ }^{169}$

\subsubsection{Mens Rea}

The mens rea for both offences in Article 140quinquies CC is a form of special intent: with a view to commit or contribute to the commission of one of the offences referred to in Article 137, with the exception of the offence referred to in Article 137, $33,6^{\circ} .{ }^{170}$ Thus, the mens rea also requires the training has to be received or undertaken with the view to commit or contribute to the commission of terrorism stricto sensu, with the exception of threatening a terrorist attack. In section 1 of the article, the part 'or contribute to the commission of' was added in $2019^{171}$, because this is part of the wording of the Directive and the legislature wanted to increase coherence (see above). ${ }^{172}$ Section 2 of the article was only introduced in 2019, with

\footnotetext{
161 Toelichting bij wetsvoorstel van 6 februari 2019 (n 8) 106; Delhaise (n 16) 60-61; Winants (n 6) 357.

162 Consideration 11 Directive (EU) 2017/541 (n 4); Toelichting bij wetsvoorstel van 6 februari 2019 (n 8) 106.

${ }^{163}$ De Coensel (n 21) 213-214.

164 Toelichting bij wetsvoorstel van 6 februari 2019 (n 8) 106; Winants (n 6) 357.

165 Winants (n 6) 351.

${ }^{166}$ Fransen and Kerkhofs (n 16) 67.

${ }^{167}$ Art 19 Directive (EU) 2017/541 (n 4). Originally art 9 Council Framework Decision 2002/475/JHA (n 2).

${ }^{168}$ Art 6, $1^{\circ}$ ter and 10ter, $4^{\circ}$ VTSv. See also: De La Serna (n 6) 209; Hameeuw (n 15) 10-11; Weyembergh and Kennes (n 6) 155; Winants (n 6) 349.

${ }^{169}$ MvT bij wetsontwerp van 13 november 2012 (n 7) 16; Fransen and Kerkhofs (n 16) 67-68.

${ }^{170}$ Art 140quinquies CC; Delhaise (n 16) 62; Fransen and Kerkhofs (n 16) 68.

${ }^{171}$ Art 79, $1^{\circ}$ wet van 5 mei 2019 (n 21); De Coensel (n 21) 212; Winants (n 6) 357.

${ }^{172}$ Art 8 Directive (EU) 2017/541 (n 4); Toelichting bij wetsvoorstel van 6 februari 2019 (n 8) 106.
} 
this phrase already in it. Concreteness is not required, so the person receiving or undertaking the training does not need to know the exact terrorist offence for which he is training. ${ }^{173}$

\subsection{Terrorist travel}

\subsubsection{Actus Reus}

When the issue of foreign terrorist fighters took the foreground, the UN Security Council issued a resolution stating member states should criminalize terrorist travel. ${ }^{174}$ Similar provisions were included in an additional protocol to the Council of Europe Convention on the Prevention of Terrorism and in the Directive. ${ }^{175}$ The Belgian legislature fulfilled these international obligations by introducing Article 140sexies into the Criminal Code. ${ }^{176}$ The actus reus of this offence is leaving ${ }^{177}$ or entering ${ }^{178}$ the national territory. The wording of the article implies the actus reus is present once the person crosses the Belgian border, not when he starts or ends his journey. ${ }^{179}$

\subsubsection{Mens Rea}

The mens rea is the aim to commit or contribute to the commission, in Belgium or abroad, of one of the offences meant in Article 137, 140 to 140quinquies and $141 \mathrm{CC}$, with the exception of the offence in Article 137, $\$ 3,6^{\circ}$. This covers all terrorist offences under Belgian law, except for threatening a terrorist offence stricto sensu ${ }^{180}$ and preparing a terrorist offence stricto sensu ${ }^{181}$. This is broader than the Directive, which does not include incitement and recruitment but at the same time it is also slightly narrower since the Directive does not exclude threatening. Concreteness is not required, so the traveler does not need to know exactly which terrorist offence he will commit. ${ }^{182} A$ fortiori it is not required that the intended offence is

\footnotetext{
${ }^{173}$ Delhaise (n 16) 62; Fransen and Kerkhofs (n 16) 68; Winants (n 6) 351.

${ }^{174}$ UNSC Resolution 2178 (n 1). See also: MvT bij wetsontwerp van 22 juni 2015 tot versterking van de strijd tegen terrorisme, Parl.St. Kamer 2014-15, nr. 54-1198/001, 5; Blaise and Delhaise (n 26) 173-174; De Coensel (n 70) 220; Velaers (n 1) 787.

${ }^{175}$ Art 4 Additional Protocol to the Council of Europe Convention on the Prevention of Terrorism, 2015, CETS 217; Art 9 Directive (EU) 2017/541 (n 4); G Stessens, 'Terroristen op reis: over de strafbaarstelling van reizen met terroristisch oogmerk en andere maatregelen ter beperking van de reisvrijheid van (vermeende) terroristen' in S Dewulf (ed), La [CVDW] Liber Amicorum Chris Van den Wyngaert (Maklu 2017) 443-445.

${ }^{176}$ Art 2 wet van 20 juli 2015 tot versterking van de strijd tegen het terrorisme, BS 5 augustus 2015, 49326; MvT bij wetsontwerp van 22 juni 2015 (n 174) 5.

177 Art 140 sexies, $1^{\circ} \mathrm{CC}$.

${ }^{178}$ Art 140 sexies, $2^{\circ} \mathrm{CC}$.

${ }^{179}$ Delhaise (n 16) 63-64.

${ }^{180}$ Art $137, \S 3,6^{\circ} \mathrm{CC}$.

${ }^{181}$ Art 140septies CC.

${ }^{182}$ Fransen and Kerkhofs (n 32) 180; Fransen and Kerkhofs (n 16) 72; Winants (n 6) 352.
} 
actually committed. ${ }^{183}$ This is a special intent, which needs to be present at the moment of the actus reus, being the traveling. ${ }^{184}$

In 2019, the scope of Article 140sexies CC was further extended. Similar to many of the other terrorist offences, the Directive requires member states to criminalize not only travel to commit a terrorist offence, but also travel to contribute to the commission of such an offence. ${ }^{185}$ As a result, the legislature inserted the words 'or contributing to the commission' twice (both for leaving and for entering the national territory) in Article 140sexies CC. ${ }^{186}$ Many of these actions were already punishable under (attempted) Article $140 \mathrm{CC}$ or (participation in) one of the other terrorist offences lato sensu ${ }^{187}$. Nevertheless, the legislature wanted to increase coherence and legal certainty and therefore thought the addition necessary. ${ }^{188}$ Again, while increasing coherence, this also increased overlap and this while the Belgian traveling offence is broader already than required by the Directive.

\subsection{Preparing a terrorist attack}

\subsubsection{Actus Reus}

In 2016, the legislature introduced further restrictions to curtail terrorism. ${ }^{189}$ In this context, they criminalized preparatory actions, because a terrorist offence is often impossible without these actions. ${ }^{190}$ The Directive does not contain a similar offence. Indeed, it simply states that criminalizing preparatory acts undertaken by a person entering a member state with the intention to commit or contribute to the commission of terrorism stricto sensu is a way to respond to terrorist travel. ${ }^{191}$ Article 140septies CC criminalizes persons who prepare a terrorist offence as defined in Article $137 \mathrm{CC}$, with the exception of Article 137, $\$ 3,6^{\circ}$. This relates to every terrorist offence stricto sensu except those threatening terrorism.

\footnotetext{
${ }^{183}$ MvT bij wetsontwerp van 22 juni 2015 (n 174) 6; Blaise and Delhaise (n 26) 174; Fransen and Kerkhofs (n 16) 70; Delhaise (n 16) 65; Winants (n 6) 352.

${ }^{184}$ Advies 57.127/AV van de Raad van State van 24 maart 2015, Parl.St. Kamer 2014-15, nr. 54-1198/001, 18; Fransen and Kerkhofs (n 32) 179-180; Fransen and Kerkhofs (n 16) 70-71; Delhaise (n 16) 65; Winants (n 6) 352.

${ }^{185}$ Art 9 Directive (EU) 2017/541 (n 4).

${ }^{186}$ Art 80 wet van 5 mei 2019 (n 21 Error! Bookmark not defined.); Toelichting bij wetsvoorstel van 6 februari 2019 (n 8) 106-107; De Coensel (n 21) 212; Winants (n 6) 357.

187 Meaning: all other terrorist offences next to terrorism stricto sensu (art $140-141 \mathrm{CC}$ ), all of which are discussed in this article.

188 Toelichting bij wetsvoorstel van 6 februari 2019 (n 8) 104-105.

189 Samenvatting van wetsvoorstel van 13 januari 2016 tot wijziging van het Strafwetboek wat betreft de bestraffing van terrorisme, Parl.St. Kamer 2015-16, nr. 54-1579/001, 1.

190 Toelichting bij wetsvoorstel van 13 januari 2016 (n 80) 4.

${ }^{191}$ Art. 9.2 (b) Directive (EU) 2017/541 (n 4).
} 
The second paragraph of the article includes a list of actions that can be preparation, e.g. gathering information on and observing locations, occurrences, events or people which makes it possible to carry out a terrorist attack (including online observation) ${ }^{192}$ and purchasing, transporting, manufacturing or searching for objects or substances which are of such a nature that they can be dangerous to other people or cause substantial economic damage, like explosives, or materials to create explosives ${ }^{193}$. This list, however, is non-exhaustive. ${ }^{194}$ Any act can be an act of preparation, depending on the context, and omissions can also be a form of preparation. ${ }^{195}$ The Council of State found that a non-exhaustive list does not necessarily violate the legality principle, on the condition that the general description of the offence is sufficiently detailed, clear and predictable. ${ }^{196}$ On the one hand the list needed to be non-exhaustive because terrorism is a changeable form of criminality. ${ }^{197}$ On the other hand, some type of list was needed in order to delimit the offence and to indicate the type of conduct particularly intended. ${ }^{198}$ The preparatory works state that it is not the intention to target people who provide limited and non-decisive help. ${ }^{199}$ However, that help can be considered as aiding and abetting the preparation of a terrorist offence or financing terrorism. ${ }^{200}$ This is another offence with an open-ended and broad actus reus and therefore there is a strong importance on the mens rea. ${ }^{201}$

Preparation is not to be confused with an attempted offence. Under Belgian criminal law, there is an attempted offence, if the intention to commit the offence has been manifested by external acts which constitute the beginning of the commission of that offence and which have ceased or have missed their effect solely as a result of circumstances beyond the control of the perpetrator. ${ }^{202}$ In general criminal law, preparatory actions that are not the beginning of

\footnotetext{
192 Amendement nr. 1 bij wetsvoorstel van 13 januari 2016 (n 127) 9; Fransen and Kerkhofs (n 16) 76.

193 Ibid.

${ }^{194}$ Delhaise (n 16) 69; Fransen and Kerkhofs (n 16) 75; Winants (n 6) 356.

195 Amendement nr. 1 bij wetsvoorstel van 13 januari 2016 (n 127) 10; Fransen and Kerkhofs (n 16) 76; Winants (n 6) 356.

${ }^{196}$ Advies 59.789/3 van de Raad van State (n 84) 13; Fransen and Kerkhofs (n 16) 75. Delhaise (n 16) 69.

${ }^{197}$ Fransen and Kerkhofs (n 16) 75.

198 Amendement nr. 1 bij wetsvoorstel van 13 januari 2016 (n 127) 10.

${ }^{199}$ Ibid 3; Fransen and Kerkhofs (n 16) 75.

${ }^{200}$ Amendement nr. 1 bij wetsvoorstel van 13 januari 2016 (n 127) 3.

${ }^{201}$ MvT bij wetsontwerp van 5 juli 2016 houdende diverse bepalingen ter bestrijding van terrorisme (III), Parl.St. Kamer 2015-16, nr. 54-1951/001, (4) 25-26 and 29; Advies 59.789/3 van de Raad van State (n 84) 10; Delhaise (n 16) 69; Fransen and Kerkhofs (n 16) 75; Winants (n 6) 355.

202 Art 51 CC; Delhaise (n 16) 81; De Nauw and Deruyck (n 22) 69-71; Vandermeersch (n 144) 82-88.
} 
the commission of the offence are not punishable. ${ }^{203}$ The idea behind criminalizing preparatory acts, is not to wait for the beginning of the commission of the offence but intervene sooner. ${ }^{204}$ However, the preparatory works explain that sometimes actions listed as preparation can be a beginning of the commission of the offence as well, depending on the circumstances of the case. $^{205}$

\subsubsection{Mens Rea}

As was the case for Article 140ter CC, the mens rea is not explicitly in the text of Article 140septies CC either. The preparatory works explain that next to the actus reus the intention to commit a terrorist offence as described in Article $137 \mathrm{CC}$ is necessary. ${ }^{206}$ The action never suffices. This intention is a form of special intent and for this offence there is a requirement of concreteness: the prosecution has to prove which offence was intended. ${ }^{207}$ The Council of State emphasized the importance of concrete and consistent factual elements that provide proof of the intention to commit a terrorist offence. ${ }^{208}$ However, this intent is not quite clear. On the one hand, the preparatory works explain that an offence prepared by one person can also be executed by another. ${ }^{209}$ On the other hand, they state that the mens rea is the intention to commit a terrorist offence. If someone prepares a terrorist offence for somebody else, he does not have the intention of committing one himself. The Council of State pointed towards this inconsistency and asked for clarification. ${ }^{210}$ The legislature did not amend the article but did explain to the Council of State that Article 140septies CC is only meant to target people who

\footnotetext{
${ }^{203}$ Winants (n 6) 355. Other statutes that criminalise preparatory actions are the statute on combating piracy at sea and the statute on the trade of narcotics. See: art 3, § 1, c), wet van 30 december 2009 (n 17); art 2bis, $\S 6$ and 2quater, $6^{\circ}$ wet van 7 februari 2014 tot wijziging van de wet van 24 februari 1921 betreffende het verhandelen van gifstoffen, slaapmiddelen en verdovende middelen, psychotrope stoffen, ontsmettingsstoffen en antiseptica en van de stoffen die kunnen gebruikt worden voor de illegale vervaardiging van verdovende middelen en psychotrope stoffen, $B S 6$ maart 1921, 1834; Amendement nr. 1 bij wetsvoorstel van 13 januari 2016 (n 127) 6. ${ }^{204}$ Amendement nr. 1 bij wetsvoorstel van 13 januari 2016 (n 127) 5; Fransen and Kerkhofs (n 16) 76.

${ }^{205}$ Ibid. This has been made clear in the case law as well. The correctional court and court of appeal of Brussels convicted defendants for participating in an attempted terrorist attack because they had, among other things, fabricated false documents, searched for a safe house, rented vehicles, and bought weapons and materials to build explosives (Brussel 31 maart 2017, 34-36; Corr. Brussel 5 juli 2016). All these things are listed as possible preparatory actions in the Criminal Code.

${ }^{206}$ Amendement nr. 1 bij wetsvoorstel van 13 januari 2016 (n 127) 8; Fransen and Kerkhofs (n 16) 77.

${ }^{207}$ Advies 59.789/3 van de Raad van State (n 84) 14; Verslag van de eerste lezing namens de tijdelijke commissie 'terrorismebestrijding' bij wetsvoorstel van 13 januari 2016 tot wijziging van het Strafwetboek wat betreft de bestraffing van terrorisme, Parl.St Kamer 2015-16, nr. 54-1579/008, 5-6; Delhaise (n 16) 71; Fransen and Kerkhofs (n 16) 77.

${ }^{208}$ Advies 59.789/3 van de Raad van State (n 84) 12; Fransen and Kerkhofs (n 16) 77.

${ }^{209}$ Amendement $\mathrm{nr} .1$ bij wetsvoorstel van 13 januari 2016 (n 127) 3.

${ }^{210}$ Advies 59.789/3 van de Raad van State (n 84) 12; advies 59.147/3 van de Raad van State State bij wetsontwerp van 6 juli 2016 houdende diverse bepalingen ter bestrijding van terrorisme (III), Parl.St. Kamer 2015-16, nr. 541951/001, (19) 27-28.
} 
prepare their own terrorist offence. ${ }^{211}$ People preparing another's terrorist offence, are potentially liable as accomplices.

\subsection{Financing a terrorist}

\subsubsection{Actus reus}

The final Belgian terrorist offence is a first-generation offence, introduced in 2003. ${ }^{212}$ This offence was not included in the Framework Decision, but in the International Convention for the Suppression of the Financing of Terrorism, signed by Belgium on 27 September 2001. ${ }^{213}$ Currently, Article 11 of the Directive includes the offence of terrorist financing.

This offence was not included in the first draft bill of the 2003 statute because Article $140, \S 1 \mathrm{CC}$ already explicitly refers to the financing of terrorism. However, the Council of State noted that Article 140 CC. only covered a certain form of financing, namely the financing of a terrorist group. ${ }^{214}$ As the financing of individual terrorists was also of interest to the legislature, Article $141 \mathrm{CC}$ was inserted. ${ }^{215}$

The offence introduced in 2003 criminalized 'any person who except in the cases referred to in Article 140, provides material resources, including financial assistance, with a view to committing a terrorist offence referred to in Article 137'. ${ }^{216}$ However, in its recommendations, the Financial Action Task Force (hereafter FATF) stressed that terrorist financing offences should not require that the funds are linked to a specific terrorist act. ${ }^{217}$ According to the FATF, collecting or providing funds to one or two people (i.e. outside of the situation of Article $140 \mathrm{CC}$ ) does not seem to be covered by Article $141 \mathrm{CC}$, if the connection

\footnotetext{
${ }^{211}$ Advies 59.789/3 van de Raad van State (n 84) 17; Verslag van de eerste lezing namens de tijdelijke commissie 'terrorismebestrijding' bij wetsvoorstel van 13 januari 2016 (n 207) 5; Fransen and Kerkhofs (n 16) 75; Winants (n 6) 356. Contra: Delhaise (n 16) 70-71.

${ }^{212}$ Art 7 wet van 19 december 2003 (n 58).

213 Art 2 International Convention for the Suppression of the Financing of Terrorism (New York 9 December 1999); De La Serna (n 6) 193; Hameeuw (n 15) 9; Winants (n 6) 349.

${ }^{214}$ Advies 34.362/4 van de Raad van State (n 53) 40.

${ }^{215}$ MvT bij wetsontwerp van 6 oktober 2003 (n 48) 9 and 14-15; Verslag namens de commissie van justitie bij wetsontwerp van 6 oktober 2003 (n 33) 23; De La Serna (n 6) 192-193; Hameeuw (n 15) 9; Weyembergh and Kennes (n 6) 154; Winants (n 6) 348.

${ }^{216}$ Art $141 \mathrm{CC}$ as introduced by art 7 wet van 19 december 2003 (n 58). Own translation, original in Dutch and French. See also: Fransen and Kerkhofs (n 16) 78.

217 Recommendation 5 FATF international standards on combating money laundering and the financing of terrorism \& proliferation, updated June 2019, 11, <www.fatfgafi.org/media/fatf/documents/recommendations/pdfs/FATF\%20Recommendations\%202012.pdf $>$ (accessed 12 June 2020). See in the original recommendations as well: FATF IX Special Recommendations, October 2001, 5, $<$ www.fatf-gafi.org/media/fatf/documents/reports/FATF\%20Standards $\% 20$ -

$\% 20 \mathrm{IX} \% 20$ Special\%20Recommendations\%20and\%20IN\%20rc.pdf> (accessed 12 June 2020).
} 
to a specific terrorist offence cannot be established. Therefore, Article 141 did not fully comply with this recommendation. ${ }^{218}$ In order to resolve this issue, the article was amended in $2016 .{ }^{219}$ Three slightly different amendments were proposed, but in the end the one that resembled the EU Directive most closely was preferred. ${ }^{220}$

The current version of Article $141 \mathrm{CC}$ criminalizes the direct or indirect provision or collection of material resources, including financial assistance, by any means. ${ }^{221}$ Compared to the original article, Article 141 is now not only aimed at people who provide resources but also those who collect them. ${ }^{22}$ The legislature notes that the wording of the new article is broader than the original one, but that this does not necessarily mean that the original article did not encompass the elements that were made more specific in the new wording. ${ }^{223}$ For example, the Directive includes providing or collecting funds, by 'any means, directly or indirectly'. ${ }^{224}$ The legislature copied this to the new Article $141 \mathrm{CC}$, but explicitly stated that this does not mean it was not already covered in the original article. ${ }^{225}$ The words 'material resources, including financial assistance' were not altered. According to the FATF they were already sufficiently broad. $^{226}$

\subsubsection{Mens Rea}

The mens rea is a special intent, for which there are two options. ${ }^{227}$ The resources have to be provided or collected with the intention that they be used, or in the knowledge that they are to be used, in full or in part, $\left(1^{\circ}\right)$ to commit or contribute to the commission of a terrorist offence stricto sensu or lato sensu $\mathrm{s}^{228}$, or $\left(2^{\circ}\right)$ by another person when the person providing or

\footnotetext{
${ }^{218}$ FATF, Anti-money laundering and counter-terrorist financing measures -Belgium, Fourth Round Mutual Evaluation Report (2015) 160, <www.fatf-gafi.org/publications/mutualevaluations/documents/mer-belgium2015.html $>$ (accessed 12 June 2020).

${ }^{219}$ Amendement nr. 2 bij wetsvoorstel van 13 januari 2016 tot wijziging van het Strafwetboek wat betreft de bestraffing van terrorisme, Parl.St. Kamer 2015-16, nr. 54-1579/005, 11-12.

${ }^{220}$ Verslag van de eerste lezing namens de namens de tijdelijke 'terrorismebestrijding' bij wetsvoorstel van 13 januari 2016 (n 207) 14; Amendement nr. 3 bij wetsvoorstel van 13 januari 2016 tot wijziging van het Strafwetboek wat betreft de bestraffing van terrorisme, Parl.St. Kamer 2015-16, nr. 54-1579/007, 2-3; Fransen and Kerkhofs (n 16) 79; Winants (n 6) 356.

${ }^{221}$ Art 141 CC; Delhaise (n 16) 72.

${ }^{222}$ Amendement nr. 3 bij wetsvoorstel van 13 januari 2016 (n 220) 4; Fransen and Kerkhofs (n 16) 79; Winants (n 6) 356.

${ }^{223}$ Amendement nr. 3 bij wetsvoorstel van 13 januari 2016 (n 220) 3-4.

${ }^{224}$ Art 11.1 Directive (EU) 2017/541 (n 4).

${ }^{225}$ Amendement nr. 3 bij wetsvoorstel van 13 januari 2016 (n 220) 4; Fransen and Kerkhofs (n 16) 79.

${ }^{226}$ FATF (n 218) 159. See also: ibid; Winants (n 6) 356.

${ }^{227}$ Delhaise (n 16) 72-73; Winants (n 6) 356.

${ }^{228}$ Meaning: all other terrorist offences next to terrorism stricto sensu (art $140-141 \mathrm{CC}$ ), all of which were discussed in this article.
} 
collecting the resources knows that this other person is committing or will commit terrorism stricto sensu. ${ }^{229}$ This is significantly broader than the mens rea from 2003.

$1^{\circ}$ is a copy from the Directive. ${ }^{230}$ Compared to the original article, $1^{\circ}$ expanded the offences of which the financing is criminalized from terrorism stricto sensu to all terrorist offences, including participating in the activities of a terrorist group and preparing a terrorist offence. ${ }^{231}$ Furthermore, the legislature ensured that a connection with a specific terrorist act was not required. The new wording clarified that it is not necessary the resources are actually used or that the perpetrator knows which specific offences they will be used for. ${ }^{232}$ This is explicitly required by the Directive when the financing concerns terrorism stricto sensu, terrorist offences relating to a terrorist group or traveling for terrorist purposes. ${ }^{233}$ Belgium, however, deemed this too restrictive and the legislature clarified that it also applies for the other terrorist offences. ${ }^{234}$

In $2^{\circ}$ the legislature emphasized that helping an individual terrorist is also an offence, as required by the FATF. ${ }^{235}$ The legislature stated that the Council of State did not express any objections about this. ${ }^{236}$ This is strange because the Council of State had questioned the distinction between $1^{\circ}$ and $2^{\circ}$. According to the Council, $1^{\circ}$ already includes financing an individual terrorist. ${ }^{237}$ The legislature never replied to this observation, even though the Council of State was correct. Providing resources in the knowledge that they are to be used to commit a terrorist offence stricto sensu $\left(1^{\circ}\right)$ or providing them in the knowledge that they are to be used by another person when the person providing or collecting the resources knows that this other person is committing or will commit terrorism stricto sensu $\left(2^{\circ}\right)$ is the same thing. ${ }^{238}$ Therefore, $1^{\circ}$ includes $2^{\circ}$, making the latter moot. By not adhering to the wording of the Directive, but

\footnotetext{
${ }^{229}$ Art $141 \mathrm{CC}$.

${ }^{230}$ Art 11.1 Directive (EU) 2017/541 (n 4); Amendement nr. 3 bij wetsvoorstel van 13 januari 2016 (n 220$) 5$.

${ }^{231}$ Amendement nr. 3 bij wetsvoorstel van 13 januari 2016 (n 220) 5; Fransen and Kerkhofs (n 16) 80.

232 Amendement nr. 3 bij wetsvoorstel van 13 januari 2016 (n 220) 5-6; Fransen and Kerkhofs (n 16) 79; Winants (n 6) 356. Although under the old wording, it could be argued that it was not required that the terrorist act was committed either. See: De La Serna (n 6) 194.

${ }^{233}$ Art 11.2 Directive (EU) 2017/541 (n 4).

${ }^{234}$ Amendement nr. 3 bij wetsvoorstel van 13 januari 2016 (n 220) 6.

${ }^{235}$ Ibid; Amendement nr. 1 bij wetsvoorstel van 13 januari 2016 (n 127) 12.

${ }^{236}$ Amendement nr. 3 bij wetsvoorstel van 13 januari 2016 (n 220) 6.

${ }^{237}$ Advies 59.789/3 van de Raad van State (n 84) 21-22; Advies 59.147/3 van de Raad van State (n 210) 31-32; Delhaise (n 16) 73. Fransen and Kerkhofs (n 16) 80.

${ }^{238}$ Delhaise (n 16) 73.
} 
unnecessarily adding $2^{\circ}$, the Belgian legislature created confusion about $1^{\circ}$, making the scope of the offence less clear.

\section{Broadness, vagueness and overlap}

The introduction of most of the aforementioned offences was challenged before the Belgian Constitutional Court indicating their apparent broadness and vagueness. Indeed, an appeal for nullification was filed against the introduction of Articles 137 and $138 \mathrm{CC}$, based on the legality principle and the prohibition of discrimination. ${ }^{239}$ The introduction of Articles 140bis to 140 quinquies CC was appealed as well, again based on the legality principle and the

freedom of expression and association. ${ }^{240}$ The introduction of Article 140sexies CC, finally, was appealed based on the principle of legality and the free movement of persons. ${ }^{241}$ All these appeals were rejected by the Constitutional Court, which makes the risk element of the offence of Article 140bis CC (see above) the only part of the terrorist offences that was annulled to date.

As the Directive sets out a broad range of acts that should be punishable in Member States, Member States are free to choose how it is implemented. Belgium chose to create new offences for every act the Directive lists while closely adhering to the wording of the Directive. The goal of these offences is to intervene as early as possible and prevent prospective terrorists from attempting to perpetrate an attack. ${ }^{242}$ One of the state's main duties is to prevent harm befalling its citizens. ${ }^{243}$ This is reflected in for example the ECHR, which imposes a positive obligation upon states to protect the right to life of the people under their jurisdiction and to protect them against inhuman or degrading treatment and torture. ${ }^{244}$ This need to prevent leads

\footnotetext{
${ }^{239}$ Arbitragehof 13 juli 2005, nr. 125/2005, B.4. See also: ibid 34-35; De La Serna (n 6) 175-176; Fransen and Kerkhofs (n 16) 21; Weyembergh and Kennes (n 6) 157. Some of the legal doctrine also argued that the offence violated the legality principle. See: Hameeuw (n 15) 6; Philip Traest, 'Ontwikkeling van nieuwe deelnemingsvormen' [2007] Nullum Crimen 241, 256-257. Flore, on the other hand, was of the opinion the offence did not violate the legality principle. See: Daniel Flore, 'La Loi Du 19 Décembre 2003 Relative Aux Infractions Terroristes: Genèse, Principes et Conséquences', Questions d'actualité de droit pénal et de procédure pénale (Bruylant 2005) 213-214.

${ }^{240}$ GwH 28 januari 2015, 9/2015, TVW 2015, 179; Winants (n 6) 351.

${ }^{241}$ GwH 18 januari 2018, 8/2018, Nieuw Juridisch Weekblad 2018, 299-304, noot W Yperman; See also: De Coensel (n 70) 239; Louise Reyntjens and Ward Yperman, 'Terrorisme En Internationale Mobiliteit Een Coherent Beleid of Nattevingerwerk' [2019] Politie \& Recht 99, 106; Winants (n 6) 352-353. This makes the offences in Articles 140,140septies and $141 \mathrm{CC}$ the only ones not challenged to date.

${ }^{242}$ MvT bij wetsontwerp van 5 juli 2016 (n 201) 25-26; Advies 59.789/3 van de Raad van State (n 84) 10.

${ }^{243}$ Andrew Ashworth and Lucia Zedner, Preventive justice (Oxford University Press, 2014), 7-10.

${ }^{244}$ Opuz v Turkey App no 33401/02 (ECHR, 9 June 2009); Z and others v the United Kingdom App no 29392/95 (ECHR Grand Chamber, 10 May 2001); LCB v the United Kingdom App no 14/1997/798/1001 (ECHR, 9 June
} 
to offences such as participating in the activities of a terrorist group, traveling for terrorist purposes, or self-study, which have very broad actus rei which include daily neutral actions. This makes the mens rea the core element of the offence. The mens rea is internal and always has to be inferred. ${ }^{245}$ Therefore, it has an inherent vagueness and offences with a strong focus on the mens rea are inevitably also quite vague. ${ }^{246}$ The danger in having broad offences with a focus on the mens rea is that mere thoughts become punishable, whereas (in Belgium and many other states) the principle is that only acts are punishable. ${ }^{247}$ Criminalizing mere thoughts invades an individual's private world and fails to treat him or her as a moral agent capable of changing their mind. ${ }^{248}$ Regarding the offence of traveling for example, the Belgian Council of State noted that it is situated on the border between the material and the intentional by criminalizing an everyday action. ${ }^{249}$ These broad and vague offences have to be applied cautiously because this broadness and vagueness does not sit well with the requirement of the legality principle that offences are clearly defined in the law. ${ }^{250}$ Part of this is due to the broadness and vagueness of the actions the Directive requires the Member States to criminalize.

Belgium, however, chose to go further still, in several cases. By expanding these offences, they become even broader and vaguer. For example, Belgium expanded the mens rea of the offence of participating in the activities of a terrorist group. This led to convictions for sending clothes to siblings or trying to marry. ${ }^{251}$ The Belgian legislature also created a new offence which is not part of the Directive: participating in the making of a decision in the context of a terrorist group. This is a poorly worded offence, which encompasses almost everybody who has had any relation with the group. When the legislature removed the risk requirement, which is present in the Directive, from the incitement offence, the Constitutional Court found this a violation of the freedom of expression because the offence was too broad.

\footnotetext{
1998); Osman v the United Kingdom App no 87/1997/871/1083 (ECHR, 28 October 1998); Amnesty International, 'Veiligheid \& Mensenrechten: Maatregelen tegen terrorisme en radicalisering', Brief aan de Kamer van Volksvertegenwoordigers n.a.v. hoorzittingen op 12 mei 2015, 2015, 5; Jos Silvis, 'Terrorism and Human Rights' in Koen Lemmens, Stephan Parmentier and Louise Reyntjens (eds), Human Rights with a human touch: Liber amicorum Paul Lemmens (Intersentia 2019) 656-657.

${ }^{245}$ R.A. Duff, Intention, Agency and Criminal Liability: Philosophy of Action and the Criminal Law (Blackwell 1990) 117.

${ }^{246}$ For traveling see: Advies 57.127/AV van de Raad van State (n 184) 17; Delhaise (n 16) 65; Ward Yperman, 'Heiligt het doel de middelen?' [2018] Nieuw Juridisch Weekblad 304.

${ }^{247}$ Fransen and Kerkhofs (n 32) 179; Fransen and Kerkhofs (n 16) 71.

${ }^{248}$ Ashworth and Zedner (n 243) 110.

${ }^{249}$ Advies 57.127/AV van de Raad van State (n 184) 17; Blaise and Delhaise (n 26) 174; Winants (n 6) 352.

${ }^{250}$ Art 7 ECHR; Cantoni v France App no 17862/91 (ECHR, 11 November 1996) 29; Del Rio Prada v Spain App no 42750/09 (ECHR Grand Chamber, 21 October 2013) 79.

${ }^{251}$ Corr. Brussel 14 mei 2014; Corr. Oost-Vlaanderen (afd. Gent) 16 oktober 2017, Nieuw Juridisch Weekblad 2017, 805, noot W Yperman en S Royer.
} 
In that same incitement offence, as well as the recruitment offence, the legislature added the traveling offence to the mens rea. Since the traveling offence itself has a broad mens rea, this addition makes these offences significantly broader than the ones in the Directive. In addition, it creates a strange distinction: inciting or recruiting somebody to travel to another country to receive or provide terrorist training there is punishable under Articles 140bis or 140ter CC, while inciting or recruiting them to do so in Belgium is not. The Belgian legislature also expanded the mens rea of the traveling offence itself compared to the Directive. This causes actions that are very far removed from an actual terrorist attack to be punishable. For example: inciting somebody to travel in order to recruit somebody to receive training for a terrorist attack is an offence under Belgian criminal law. ${ }^{252}$ Furthermore, with the criminalization of preparatory actions, the Belgian legislature created yet another offence with an open-ended, broad, and vague actus reus and therefore, a strong reliance on the mens rea. Finally, the Belgian legislature created a second prong to the mens rea of the offence of financing a terrorist, which is not part of the Directive. This second prong, however, is already encompassed by the first prong, only creating unnecessary confusion.

Due to this broadness and vagueness, there is a fair amount of overlap between many of these terrorist offences. For example, a message on social media calling for people to travel to Syria could be recruitment, inciting and participation in the travelling offence. Looking up certain information online could be self-study and preparation and, if accompanied by other actions, perhaps even an attempted terrorist offence stricto sensu. On top of that, if either of those things happen within the context of a terrorist group, they also fall under participation in the activities of a terrorist group. The Belgian legislature is aware of this, thus Articles 140bis to 140 sexies CC state that they apply 'without prejudice to the application of Article 140 '. ${ }^{253}$ The legislature therefore acknowledged that (some of) the actions being criminalized by these articles were already being prosecuted under Article 140 CC. They intended to alleviate all doubt about the fact that concurrent offences are possible. The practical application of these offences demonstrates that they are very often prosecuted in concurrence with Article 140 CC. ${ }^{254}$ Therefore, they have minimal added value. The question also arises regarding the impact

\footnotetext{
${ }^{252}$ Since this is a felony, both the attempt at this offence and aiding and abetting this offence are also punishable. See: art 52 and 69 CC.

${ }^{253}$ Own translation, original in Dutch and French.

${ }^{254}$ For example: Antwerpen 2 maart 2016; Antwerpen 22 december 2016; Corr. Brussel 26 juni 2015; Corr. Antwerpen 7 december 2015; Corr. Oost-Vlaanderen (afd. Dendermonde) 25 januari 2016; Corr. Brussel 20 oktober 2016; Corr. Brussel 9 maart 2017; Corr. Brussel 31 mei 2017; Corr. Henegouwen (afd. Charleroi) 27
} 
of the overlap between Articles 140bis to 140sexies. By only referring to Article $140 \mathrm{CC}$, the legislature has created the possibility for confusion. Under the general rules of Belgian criminal law, concurrence between offences is possible without this explicitly being acknowledged in the articles containing the individual offences. ${ }^{255}$ Why then did the legislature explicitly refer to Article $140 \mathrm{CC}$ but not to the other terrorist offences? One could think the legislature implicitly wanted to exclude concurrence with the other terrorist offences, but that is doubtful considering the current climate of extensive criminalization. More likely is that the legislature did not have a specific reason for including this clause and for clarity's sake it should either have included all the other articles in this clause or should have deleted it altogether. ${ }^{256}$

\section{Conclusion}

The Directive has created a wide range of acts to be criminalized by member states which Belgium has surpassed abundantly. The Belgian Constitutional Court has also been lenient when interpreting these offences. However, despite this lenient case law, the broadness and vagueness of many of the offences and the overlap between the different offences are rather obvious.

It is striking that many of the most problematic offences are those where the Belgian legislature has surpassed the Directive. Since its entry into force, the offences have only ever been expanded. Terrorism has proved to be a difficult issue to address, and the legislature has responded by creating more and broader offences. However, many of the issues mentioned above could be avoided by doing the opposite: focusing less on the quantity of offences and more on the quality. Thoroughly reviewing which behavior should be criminalized and how to phrase offences that do so. For Belgium, adhering more closely still to the Directive could be a first step towards achieving this goal. For the EU, it could mean looking more critically at the broadness of the acts it is requiring member states to criminalize and analyzing how the clarity can be improved. Expanding does not always equate to improving. Sometimes less could indeed, be more.

september 2017; Corr. Oost-Vlaanderen (afd. Dendermonde) 26 februari 2018. See also: Fransen and Kerkhofs (n 16) 57, 63-64, 65, 74 and 81.

255 Art 58-65 CC.

${ }^{256}$ Delhaise (n 16) 67. 